\title{
Perspective \\ Date Palm Pollen: Features, Production, Extraction and Pollination Methods
}

\author{
Ricardo Salomón-Torres ${ }^{1, *,+}$, Robert Krueger ${ }^{2, *,+} \mathbb{D}$, Juan Pablo García-Vázquez ${ }^{3} \mathbb{D}$, Rafael Villa-Angulo ${ }^{4}$, \\ Carlos Villa-Angulo ${ }^{4}$, Noé Ortiz-Uribe ${ }^{1}$, Jesús Arturo Sol-Uribe ${ }^{1}$ and Laura Samaniego-Sandoval ${ }^{1}$
}

1 Unidad Académica San Luis Rio Colorado, Universidad Estatal de Sonora, Sonora 83500, Mexico; sinhuet7@hotmail.com (N.O.-U.); jsoluribe@yahoo.com.mx (J.A.S.-U.); laura.samaniego@ues.mx (L.S.-S.)

2 USDA-ARS National Clonal Germplasm Repository for Citrus and Dates, Riverside, CA 92507, USA

3 Facultad de Ingeniería, Universidad Autónoma de Baja California, Mexicali, Baja California 21100, Mexico; pablo.garcia@uabc.edu.mx

4 Instituto de Ingeniería, Universidad Autónoma de Baja California, Mexicali, Baja California 21100, Mexico; rafael.villa@uabc.edu.mx (R.V.-A.); villac@uabc.edu.mx (C.V.-A.)

* Correspondence: ricardo.salomon@ues.mx (R.S.-T.); robert.krueger@usda.gov (R.K.); Tel.: +52-653-534-4255 (R.S.-T.); +1-951-827-6980 (R.K.)

+ Both authors contributed equally to this work.

check for updates

Citation: Salomón-Torres, R.; Krueger, R.; García-Vázquez, J.P.; Villa-Angulo, R.; Villa-Angulo, C.; Ortiz-Uribe, N.; Sol-Uribe, J.A.; Samaniego-Sandoval, L. Date Palm Pollen: Features, Production, Extraction and Pollination Methods. Agronomy 2021, 11, 504. https:// doi.org/10.3390/agronomy11030504

Academic Editor: Iñigo Loureiro

Received: 12 February 2021

Accepted: 5 March 2021

Published: 8 March 2021

Publisher's Note: MDPI stays neutral with regard to jurisdictional claims in published maps and institutional affiliations.

Copyright: (c) 2021 by the authors. Licensee MDPI, Basel, Switzerland. This article is an open access article distributed under the terms and conditions of the Creative Commons Attribution (CC BY) license (https:/ / creativecommons.org/licenses/by/ $4.0 /)$.

\begin{abstract}
Date palm pollen (DPP) plays a very important role in the fertilization process, since its viability and the pollination method influence on the quality, development, and yield of the fruit. In the present study, a broad review of its main characteristics, consumption, and DPP production are presented, as well as a description of its extraction methods and viability tests. The evolution of the pollination methods used in the date palm is also presented, from its natural pollination to the use of specialized mechanical and electrical devices, as well as the use of dry DPP and the current trend towards the use of DPP in liquid suspension. Likewise, the efficiency of the methods of natural pollination (wind); traditional (strands placement); dusting hand; dusting with manual, mechanical, or electric pollinator; and liquid pollination were evaluated from the fruit set percentage (FSP). Finally, starting from a scientometric analysis, the pollination methods were widely discussed, concluding that the dusting spraying of pollen suspension with liquid DPP is the pollination method that commonly presents the highest FSP, followed by dusting dry DPP with a motorized pollinator.
\end{abstract}

Keywords: date palm pollen; artificial pollination; pollen extraction; pollen production; liquid suspension pollen; Phoenix dactylifera $\mathrm{L}$.

\section{Introduction}

The date palm (Phoenix dactylifera L.) belongs to the genus Phoenix, which has 14 species of mostly ornamental or wild palms, with only Phoenix dactylifera being cultivated for its fruit [1]. It is a dioecious species, meaning that there are separate trees bearing unisexual inflorescences of staminate or pistillate flowers called "male" and "female" palms, respectively [2]. Its inflorescences, also known as racemes, grow among the axils of the leaves next to the trunk of the palm, inside a hard cover called the spathe, which opens when the inflorescence is mature [3].

The yield of date palms is mainly determined by the fruit set percentage (FSP) of the racemes. This in turn depends on various factors such as the date palm pollen (DPP) source and quality, pollination period, pollination method, female-male compatibility, and other factors such as temperature, fertilization, irrigation, and soil characteristics [4]. Pollination of the date palm occurs naturally by the action of wind. However, for commercial production, it is necessary to artificially pollinate date palms [5]. Commonly, each farmer identifies the DPP source and extraction technique that gives the best results. It is estimated that one healthy adult male palm is sufficient to pollinate up to 50 female palms [6]. 
Since ancient times, hand pollination has been practiced on the date palm through the insertion of male strands into the female inflorescences. Today, this method of pollination remains traditional in certain modern plantations with elite cultivars and in traditional oases. However, this method requires almost double the quantity of DPP compared to using dried pollen [6], requires more effort and worker experience, and does not guarantee high FSP.

Pollination is considered one of the most important processes in successful date production, since fruit yield and quality depend on the correct application of pollen. Since the middle of the last century, improved efficiency of the pollination process has been attempted, ranging from manual dusting of pollen to the use of aircraft [7]. A great diversity of hand-pollination methods have been investigated, as well as the use of mechanical, motorized, and electrical devices, and recently the use of liquid suspensions [2,8]. Some of these methods have proven to be highly efficient; however, some devices cannot be used due to their high cost, the need for operator skills, and equipment maintenance costs $[7,9,10]$.

Automation of the DPP extraction process is a prevailing need in the modern date industry. Currently there is automated equipment on the market that has suction and filtering systems, allowing the extraction of almost $100 \%$ of pure pollen. These devices regularly extract $2.5-4 \mathrm{~kg}$ of pollen per hour [11]. In contrast, the manual extraction of DPP depends largely on the skill and experience of the worker, as well as being a timeconsuming and delicate process with much lower rates of pollen extraction.

This study describes the characteristics of DPP, reviews current techniques for its extraction and application, and starting from a scientometric analysis, carries out an extensive discussion of these methods. It is concluded that the methods of liquid pollination and dusting with dry pollen present the greatest advantages over the others. These topics are quite relevant for successful production of date fruit and are of great interest to producers of this fruit.

\section{DPP Features}

\subsection{Description}

Pollen is the name given to fine dustlike grains contained in flower anthers, which are the source and transport unit for the male gametes [12]. Pollination is the process by which pollen grains are transferred from the anthers (male floral organ) to the stigma (female floral organ), where the pollen grain germinates and fertilizes the ovule of the flower, making possible the production of seeds and fruits. Germination is the process where the pollen grains, after falling into the flower stigma, generate a tube-shaped extension (pollen tube), which serves as a transport pathway for the male gametes from the pollen grain to the ovule. Fertilization occurs when the pollen tube reaches the embryo sac and discharges its genetic contents and the male gametes fuse with the female gametes of the ovules. Specifically, two sperm cells released from the pollen tube fuse with the egg cell and the central cell in the embryo sac, respectively, to give rise to a zygote and a primary endosperm, a process called double fertilization. The zygote eventually develops into a mature embryo of a seed $[13,14]$.

Male date palm flowers usually have three sepals, three petals, six stamens, and three carpels (which rarely develop parthenocarpically), and are usually waxy white. In contrast, female flowers are usually yellowish-green with three sepals, three petals, six staminodes, and three separate carpels, only one of which normally develops into a mature fruit (Figure 1C). Both male and female flowers, numbering in the hundreds, are borne on thin structures called rachillae or strands. The rachillae in turn are on borne on flat, tapering peduncles (also called rachises) originating in the axis of leaves developed during the previous growing season. These peduncles are referred to as fruit bunch stalks or fruit stalks on female trees. These structures constitute the inflorescences of the date palm. During the early stages of flower development, the inflorescences are enclosed in hard, fibrous coverings called spathes [15]. The number of inflorescences borne on each palm 
varies from none to more than 25 , depending on the age and vigor of the tree [3]. The inflorescences of male palms produce pollen (Figure 1B,C), whereas the inflorescences of the female palms include carpels that under appropriate conditions develop into the date fruit (Figure 1A,C).
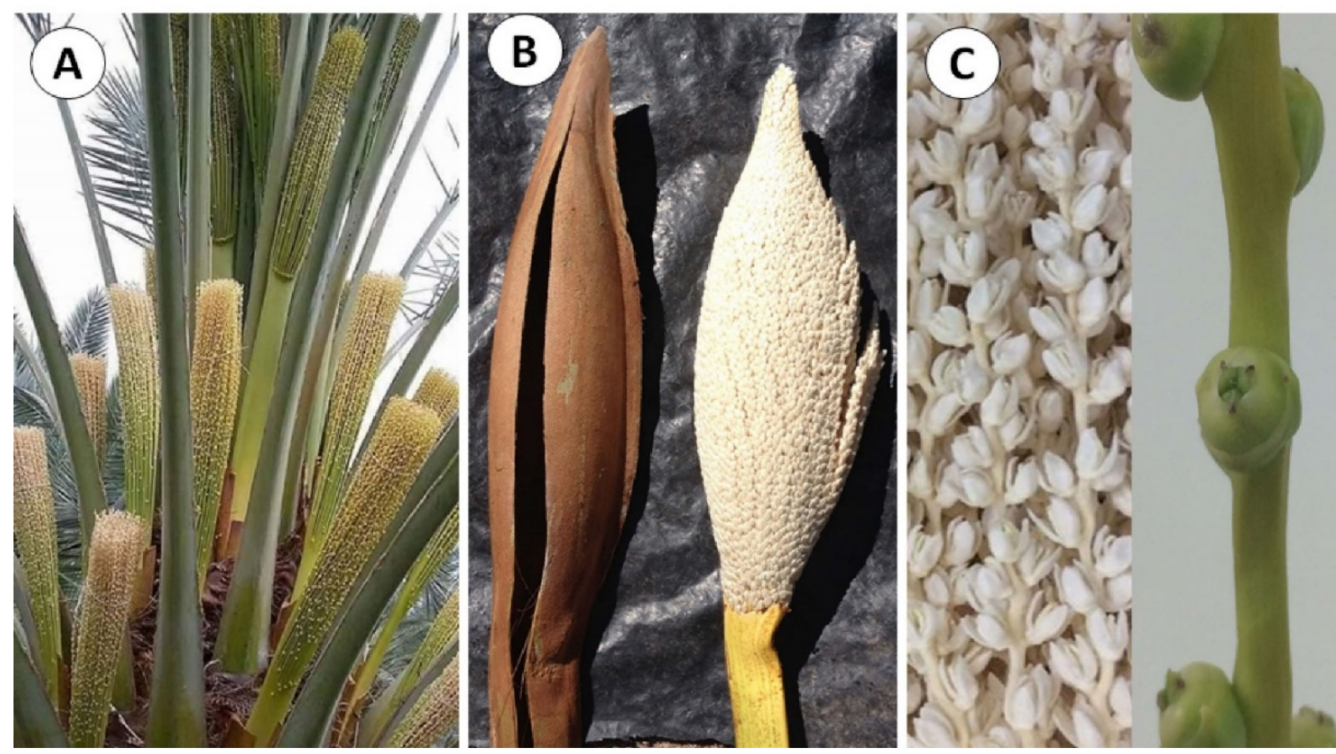

Figure 1. Male and female inflorescences on the date palm. (A) Two groups of female inflorescences with different stages of development. The inflorescences at the bottom are ready for pollination. (B) Male inflorescence (right) outside its spathe (left), in the drying process prior to the extraction of pollen. (C) Male strands (left) and a single female strand (right). Source: Images A (Adapted from [16]). B, C (Photos by Ricardo Salomón-Torres).

The pollen grains of species in the Arecaceae vary mostly in aperture and ornamentation. Pollen of Phoenix spp. in general are elliptical or boat-shaped with a single germinal furrow extending lengthwise across the polar surface, with mean lengths of 17.2-26.7 $\mu \mathrm{m}$ and mean widths of 9.7-15.6 $\mu \mathrm{m}$; length-width ratios are generally less than 2:1. The exine (outer coat of the pollen grain) usually exhibits a tectate-perforate structural pattern (showing small perforations in the tectum), with irregularly shaped holes. In some cases, a waxlike substance is present outside the exine [17].

Flowering of the date palm begins when the shade temperature increases to more than $18^{\circ} \mathrm{C}$, and fruit forms when it is higher than $25^{\circ} \mathrm{C}$ [18]. In the Northern Hemisphere, male palms normally bloom in February to March, with the female palms blooming slightly later in March and April. Inflorescences arise in the axis of the leaves, pushing through the spathe wall, causing the spathes to crack longitudinally at anthesis. Only the distal portion of the rachillae that bears flowers is exposed at this time. Later, the proximal, non-fruit bearing portion of the inflorescence lengthens and pushes out of the spathe to a length of 60-120 cm, depending on female cultivar. Male inflroescences are somewhat shorter, rarely being more than $50 \mathrm{~cm}$ in length. The elongation period lasts 50-60 days after flowering. After pollination, the fruit normally develops from one of the three carpels within each pistillate flower, while the other two carpels abort. If pollination does not occur, one or all carpels may develop into small parthenocarpic fruit that are of no commercial or nutritional value. Natural fruit abscission occurs 25-35 days after spathe crack, and some cultivars have a second abscission about 100 days after spathe crack (sometimes referred to in the Northern Hemisphere as June drop) [19].

In general, the pollen of any male palm variety is suitable for the pollination of any female variety. However, since most male palms are of seedling origin, there are large variations in the quality of their pollen. Different sources of DPP can cause many variations in fruit set, color, size, ripening time, shape, fruit-weight, seed-weight, percentage of 
pericarp, and parthenocarpic fruit formation [20,21]. It has been proposed that one of the factors in these abnormalities has been the morphology of the DPP. A recent study characterized the morphology of 11 different pollen grains, highlighting their rhomboid shape, with lengths of 17.20-21.40 $\mu \mathrm{m}$ and widths of 6.97-10.30 $\mu \mathrm{m}$. [22]. Another study reported for an elliptical shape (Figure 2C) for three different sources of DPP, with sizes of 20.38-21.94 and 16.32-16.96 $\mu \mathrm{m}$ in length and width, respectively. Likewise, for pollen of two different males, a spherical shape (Figure 2B) was reported with dimensions of 18.56-18.64 and 18.51-18.55 $\mu \mathrm{m}$ in length and width, respectively [20]. This last study evaluated the compatibility of five different DPP sources on the recipient female "Barhee" cultivar, where the elliptical-shaped pollen caused the highest percentages of abnormality in the fruit.
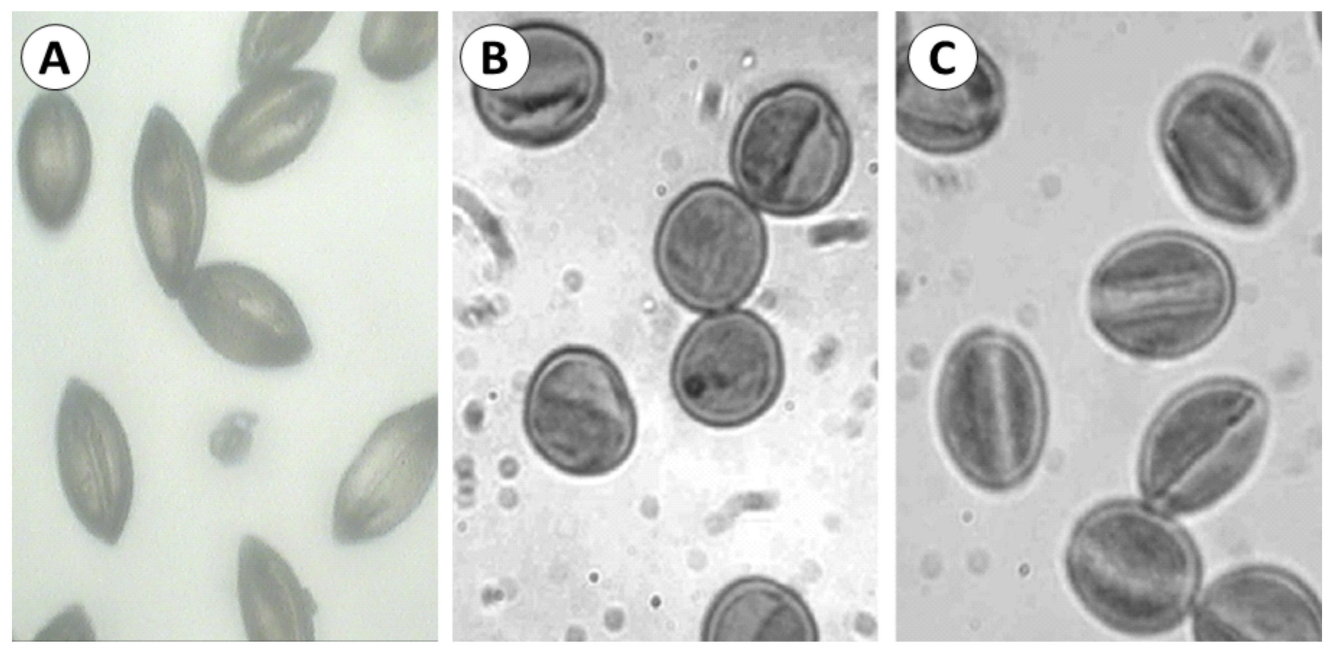

Figure 2. The shapes of pollen grains of the date palm. (A) Pollen sourced from date palm seedling male derived from the "Medjool" cultivar, with rhomboid-shaped pollen. The DPP from male trees developed from seeds of the "Deglet Noor", "Khadrawy", and "Zahidi" cultivars have also the same shape. (B) Pollen sourced from date palm seedling male derived from the "Kacst" cultivar, with spherical-shaped pollen. The DPP from a male tree developed from seed from the "Muzahmiya" cultivar also presented the same shape. (C) Pollen source from date palm seedling male derived from the "Heet" cultivar, with elliptical-shaped pollen. The DPP from male trees developed from seeds of the "Dilim" and "Fouzan" cultivars also have the same shape. Source: Image A (Photo by Ricardo Salomón-Torres). Images B, C (Adapted from [20]).

Seeking this compatibility with female cultivars so that they provide high yields, several date producing countries such as Egypt, Saudi Arabia, and Iran have already identified their DPP elite selections [6,23,24]. Recent studies in Mexico verified the compatibility among four different DPP sources (Figure 2A) with the recipient female "Medjool" cultivar $[4,25,26]$.

\subsection{DPP Effect on the Date Fruit}

Different sources of DPP have a direct influence on the fruit, an effect known as metaxenia [27]. The size, color, quality, and ripening time of the fruit are direct and precise effects of the parent male, exerting the same effect on the recipient females in different years [21]. The source of DPP also influences the size, color, and shape of the seed, a phenomenon known as xenia [28]. The endospermatic tissue is not produced by the mother plant, but is a product of fertilization and therefore is influenced by the genetic factors carried by the pollen that affect its color. Metaxenia, unlike xenia, cannot be explained by hereditary elements (chromosomes) brought by DPP, since no chromosomes are contributed to the tissues showing the direct effect of parental pollen [21]. Mobile factors from seed, which harbors the paternal genome, moves to and affects fruit development. These effects are therefore independent of the contribution of the pollen towards the next generation [21]. 
There is some confusion regarding xenia and metaxenia in the literature [29]. The original suggestion that the pollen's effects might come from differences in hormone production [30] should be tested more directly with current technology. Metaxenia is not limited to the date palm, but it is also present in other plants [31].

Due to the influence of DPP source on fruit characteristics, farmers select the pollen sources that positively influence the yield and the physical-chemical quality of the fruit. Various studies have been carried out seeking to identify the best male pollinators [20,32-35]. Studies have recently been carried out in Mexico, where the effect of pollen on nutritional properties of the fruit and seed has been analyzed in the "Medjool" cultivar $[4,25,26]$.

\subsection{Nutritional Content}

DPP is a natural source of protein, minerals, dietary fiber, vitamins, sugars, amino acids, lipids, hormones, carbohydrates, sterols and enzymes, cofactors, and antibacterial and antioxidant agents $[36,37]$. Few studies have quantified the phytochemical properties of DPP; however, it is known that it consists of water (5-36\%) and solids (64-95\%) [14]. Table 1 shows the results of various studies carried out in Tunisia, Egypt, and Iraq in which the nutritional properties of various sources of DPP were determined [36,38-40].

Table 1. Comparative analysis of the proximate chemical composition of five DPP sources.

\begin{tabular}{|c|c|c|c|c|c|}
\hline Parameter & "Deglet Noor" [36] & “El-Ghannmi Ahmar" [38] & "Khikri" [39] & "Samasmi" [39] & "El-Hayani" [40] \\
\hline Moisture (\%) & 30.31 & 8.04 & 44.88 & 39.05 & 28.8 \\
\hline Protein $(\mathrm{g} / 100 \mathrm{~g})$ & 38.18 & 19.45 & 26.93 & 23.42 & 31.11 \\
\hline Fiber $(\mathrm{g} / 100 \mathrm{~g})$ & - & 0.11 & - & - & 1.37 \\
\hline Lipids (g/100 g) & 10.24 & 7.67 & 7.20 & 8.50 & 20.74 \\
\hline Hash (g/100 g) & 6.16 & 5.85 & 4.61 & 5.68 & 4.57 \\
\hline Carbohydrates (g/100 g) & - & 26.25 & 16.27 & 22.78 & 13.41 \\
\hline
\end{tabular}

The study carried out in Tunisia [36] used DPP from the "Deglet Noor" cultivar, where characteristics such as $\mathrm{pH}(6.31)$, glucose $(3.66 \%)$, fructose $(4.48 \%)$, and sucrose $(10.08 \%)$ were also reported. The study carried out in Iraq [38] with DPP from the "El-Ghannmi Ahmar" cultivar also reported a total solids content of $91.95 \%$ and potassium, magnesium, calcium, iron, and copper as the five most abundant minerals, with concentrations of 73.5, $19.6,10.8,8.5$, and $3.65 \mathrm{mg} / \mathrm{g}$, respectively. Finally, the study carried out in Egypt [40] on DPP from the "El-Hayani" cultivar additionally reported 17 amino acids, with leucine and lysine having the highest concentrations ( $3.34 \%$ and $2.95 \%$, respectively), and 13 fatty acids, with palmitic acid $(34.45 \%)$ and linoleic acid $(14.24 \%)$ having the highest concentrations.

The chemical variation among the different DPP sources and the countries where they are grown can be related to the genetics, nutrition of the crop, and weather conditions, among other factors. The protein concentration of DPP (15.8-38.18 g/100 g) is higher than that of the date fruit $(1.1-3.0 \mathrm{~g} / 100 \mathrm{~g})$ and seed $(2.29-7.08 \mathrm{~g} / 100 \mathrm{~g})[41,42]$. The most abundant element in the DPP, as well as the date fruit and its seed, is potassium $[38,41-43]$.

\section{DPP Production and Consumption Needs}

When establishing a new date plantation, as the female palm produces the fruits, a producer generally plants the maximum number of female palms and a minimum number of males. In a modern plantation, the DPP production of one healthy adult male palm can pollinate up to 50 females [3].

It is estimated that approximately 1000 tons of DPP are produced each season by the date palms of the Arab countries [44]. An adult male date palm regularly produces an average of $500 \mathrm{~g}$ of pollen annually [3], but may produce more than $1 \mathrm{~kg}$ [45]. A study developed in Saudi Arabia quantified the pollen production by spathe of 61 seedling males, reporting that the production of DPP varies greatly among spathes from one male to another (0.02-82.29 g/spathe) [46]. Another study carried out in Algeria, reported the production of DPP in 12 adult male seedling palms [47], producing from 248 to $2133 \mathrm{~g}$, in a range of 11 to 36 spathes per palm, with an average of 19 spathes and $740 \mathrm{~g}$ per palm. 
The consumption needs of DPP to pollinate each female palm depends on the pollination method used, the cultivar to be pollinated, the age of the palm, and the number of inflorescences on each palm. It has been estimated that using hand pollination by placement of fresh male spikelets (Section 5.3), a consumption of 8-10 $\mathrm{g}$ DPP is required for each female palm with a maximum of 12 inflorescences per palm. Using a method similar to the motorized pollen duster (Section 5.6.3), $11 \mathrm{~g}$ DPP per palm is required [47].

In Mexico, a squeeze bulb is commonly used for the manual pollination (Section 5.4.1.) of the "Medjool" cultivar. Usually, the squeeze bulbs are filled with $65 \mathrm{~g}$ of dried DPP diluted in 1:1 ratio with $65 \mathrm{~g}$ of commercial wheat flour. Each squeeze bulb is able to pollinate approximately 50 inflorescences, for an average DPP consumption of $1.3 \mathrm{~g}$ per inflorescence.

Using this criterion, it is estimated that 1.5 male palms were required to pollinate 50 female "Medjool" palms, having an average of 18 inflorescences per palm. This represents a consumption of $1.17 \mathrm{~kg}$ of DPP. For the liquid suspension method with a $4 \mathrm{~g}$ pollen per L of water ratio, DPP consumption was $360 \mathrm{~g}$, which would represent having 0.5 male palms for every 50 female palms.

\section{Pollen Extraction \\ 4.1. Drying Process}

The extraction process begins when the male spathe begins to ripen on the palm (Figure 3A). A sign of maturation is when the spathe covering the male inflorescence cracks (Figure 3C) or when the lower part of the spathe dries out at its base (Figure 3B). To prevent the inflorescence from entirely emerging from the spathe and the resulting loss of pollen, the spathe is cut from the palm and brought to a temperature-controlled room $\left(18-22{ }^{\circ} \mathrm{C}\right)$, or some designated place to continue drying for several days.

The spathe is removed, leaving the inflorescence completely exposed. At this stage, the inflorescence has a high moisture content, and must be dried to avoid contamination of the pollen by mold (Figure 3D,E). In order for the DPP not to lose its viability, its contact with the sun should be avoided, so the drying process should begin in a room with low humidity (40-45\% R. H.) at ambient room temperature. As the inflorescence's moisture decreases, its flowers begin to open and release the pollen grains. After this, the pollen is ready to be extracted from the inflorescence, the hand and mechanical processes being the common methods for its extraction [3].

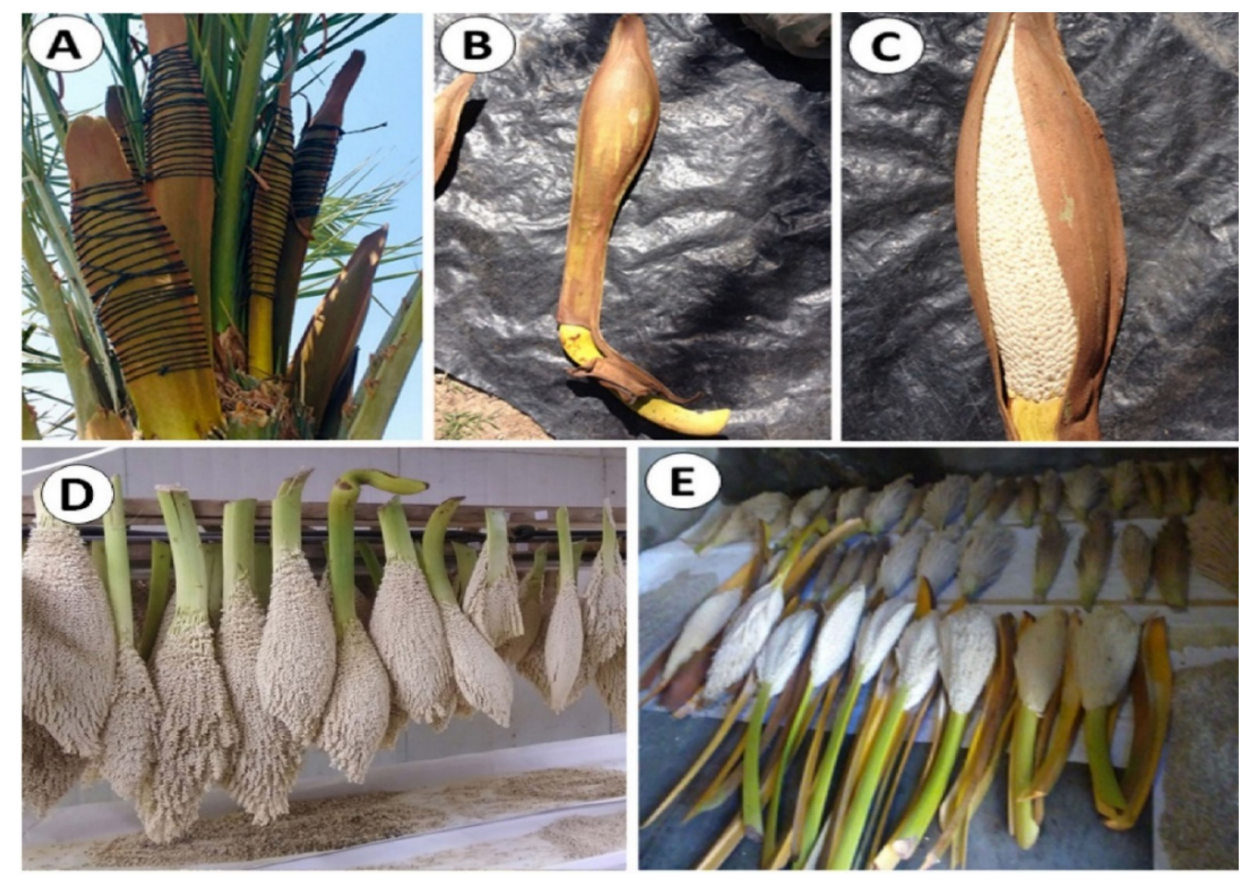

Figure 3. Cont. 

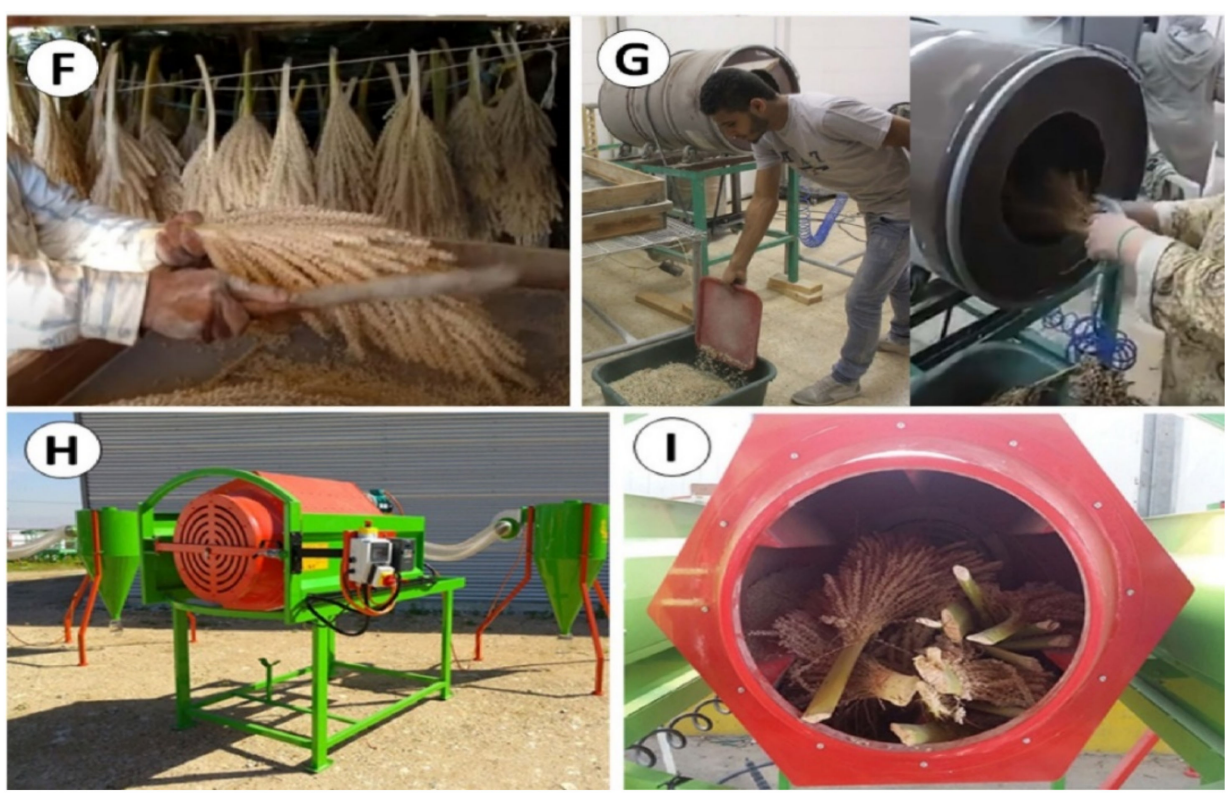

Figure 3. Date palm pollen extraction process. (A) Spathe about to open on the palm. It is common to tie and press the spathe with string so that it matures as long as possible on the palm. (B) The base of the spathe comes off, indicating that this spathe is ready to be cut. (C) Open spathe, ready to dry. (D) Hanging spathes, drying and releasing pollen grains. (E) Spathes on a layer of paper. (F) Lightly striking the inflorescence to release more pollen. (G) Pollen extraction machine, handcrafted. (H,I) Industrial and automated equipment for the extraction of pollen. Source: Images A, B, and C (Photos by Ricardo Salomón-Torres). Images D, E, F, and G (Adapted from [16,48]). Images H, I (courtesy of Agrom Agricultural Machinery, LTD, www.agrommachine.com; accessed on 22 July 2020).

\subsection{Hand Extraction}

This is the traditional method and it consists of placing the dried inflorescences on a layer of paper or hanging them for several days above a large container or paper bag. The flowers will then release their pollen onto the layer of paper or into the containers, from whence it can be collected. After the inflorescence has released most of its pollen, it is shaken and tapped lightly to release the remaining pollen (Figure 3F) [49]. Finally, the DPP obtained is filtered through a sieve to obtain pure pollen and prepare it for storage.

\subsection{Mechanical Extraction}

Devices for the mechanical extraction of pollen vary, depending on whether they are handcrafted by the farmer (Figure 3G) or manufactured industrially (Figure 3H,I). Normally this equipment consists of a rotating barrel into which mature inflorescences are inserted, a sieve to filter pollen from other materials, a suction fan, and a container that receives the extracted DPP. This type of machine can handle the extraction of up to 450 inflorescences daily, collecting approximately 40\% more DPP than the hand method. It has been reported that the use of this extraction method does not harm the viability or longevity of DPP [3].

\subsection{DPP Conservation}

Normally, the male inflorescences produce pollen in the months of February and March, while the female inflorescences are receptive to pollination between the months of March and April [5]. Sometimes due to climatic conditions, the male inflorescences delay their appearance and opening, lagging behind the flowering of the female inflorescences [50]. This represents a great risk for the farmer, due to the fact that the female inflorescence is receptive to pollen for 3-12 days after emergence, depending upon cultivar [3]. When the pollination process is carried out beyond that time period, there will be high abortion percentages or very low FSP. Likewise, FSP decrease with increasing 
time after spathe crack, with varietal differences reported [51,52]. In order to avoid this problem, many date farmers conserve pollen from the previous season for their first round of current pollination.

Fresh pollen stored under dry conditions maintains viability at room temperature $\left(24^{\circ} \mathrm{C}\right)$ for four weeks or more, which is long enough for the current pollination season [29]. However, if pollen is kept for longer periods, it needs to be stored at low temperatures in bottles or sealed plastic containers. Several studies have analyzed various methods for its conservation in periods of one year or more, using $4{ }^{\circ} \mathrm{C}$ refrigerators, -20 and $-80{ }^{\circ} \mathrm{C}$ freezers, as well as cryopreservation at $-196{ }^{\circ} \mathrm{C}$ with liquid nitrogen $[30,46,50,53,54]$. According to different viability tests, DPP underwent degradation even when preserved. However, it was concluded that cryopreserved DPP maintains almost the same germination percentage as fresh pollen [54]. It was also found that DPP stored for more than one year at a temperature of $-20{ }^{\circ} \mathrm{C}$ maintains a better percentage of germination than that stored at $4{ }^{\circ} \mathrm{C}$ [50]. Pollen stored for the next season's pollinations should be maintained in a sealed container, preferably with a desiccant, in order to maintain the pollen in a dry state [55].

\subsection{DPP Viability}

Pollen viability is the ability it has to germinate and effect fertilization, resulting in the subsequent development of fruits and seeds [56]. The application of greater amounts of DPP in the female inflorescences does not ensure high FSP, unless the DPP used is viable, has a high degree of germination, and the female flower is receptive. For this reason, it is desirable to assess the viability of DPP before the pollination process, since it is more likely that a higher yield will occur if high quality pollen is used [3].

DPP viability can be determined by various tests such as: fluorescein diacetate (FDA), Alexander's staining, absolute pollen viability, in vitro germination, and acetocarmine staining, among others $[30,53]$. The most widely used feasibility evaluation methods are in vitro germination and staining with acetocarmine.

The in vitro method consists of the germination ability of DPP on germinating medium. The medium may vary, but a common one is the use of $1 \%$ agar, $10 \%$ sucrose, and $500 \mathrm{ppm}$ boron. A pH of six for the medium is generally optimal for date palm pollen germination, but different cultivars may have different optimum $\mathrm{pH}^{\prime} \mathrm{s}$ [57]. A small amount of DPP is sprinkled or dusted with a camel hairbrush onto the medium in a petri dish. After $24 \mathrm{~h}$ at $25-27^{\circ} \mathrm{C}$ in an incubator, the growth of the pollen tube as observed under magnification is evidence of germination [46] (Figure 4A).

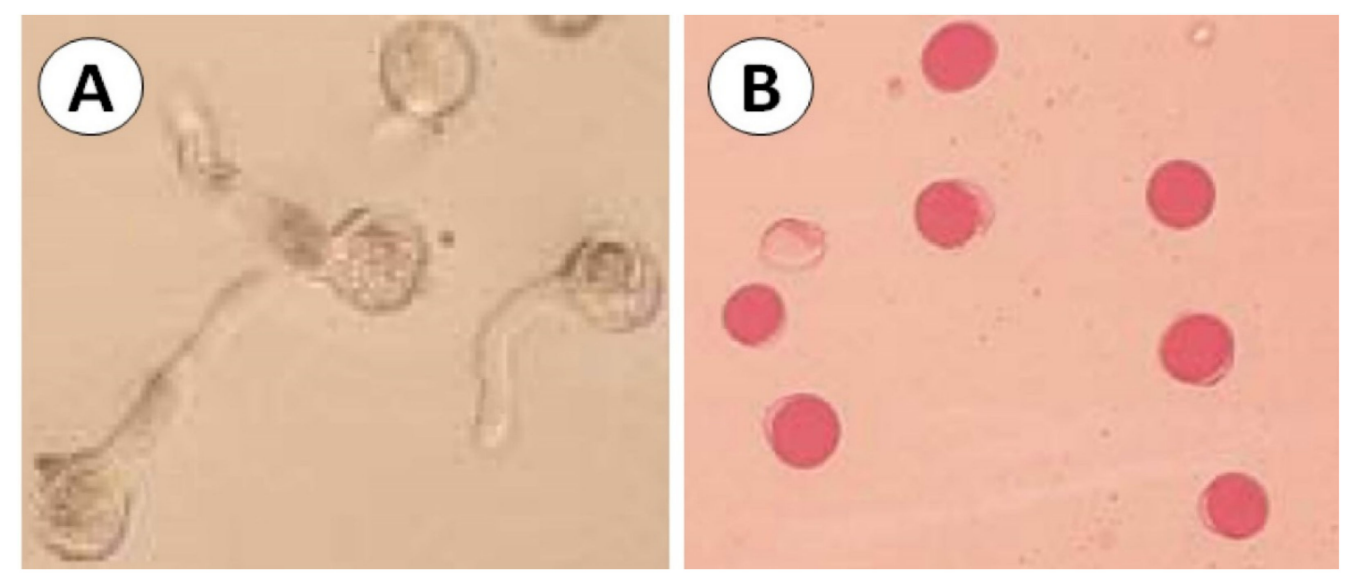

Figure 4. Two methods for determining DPP viability. (A) The germination ability on germinating medium. The growth of the pollen tube is observed as a success in viability in three germinated grains, while a non-germinated pollen grain appears in the upper part, which indicates non-viability. (B) The differential stainability of the pollen grains with acetocarmine. The red tinted dots show viability, while the unstained dot indicates non-viability. Images adapted from [53]. 
The method of differential staining of pollen grains with acetocarmine is the viability test commonly used to evaluate the germination viability [30]. This consists of adding 1-2 drops of $1 \%$ acetocarmine solution to a small amount of pollen on a slide. The slide is heated over a spirit flame, squashed, and is ready for observation 5 to $10 \mathrm{~min}$ after [58]. Pollen grains that stain red are considered viable, while colorless ones will be non-viable [46] (Figure 4B).

\section{Date Palm Pollination Methods}

\subsection{Pollination}

Cross-pollination is the transport of pollen from one plant to another by means of an external pollinating agent. Natural external pollinators are made up of abiotic and biotic agents. Abiotic pollinating agents are natural environmental elements, such as wind and water, in which pollen can travel to a female flower to fertilize. Biotic pollinating agents are insects or other animals, which carry pollen from one flower to another. Biotic pollinating agents include bees, butterflies, bats, hummingbirds, and humans, among others. Artificial external pollinators are human-devised methods to improve crop yield by more efficiently uniting the pollen and the female flower. In the case of the date palm, these methods are hand pollination with fresh spikelets or dry pollen, mechanical pollination with dry pollen, and pollination with a liquid suspension of pollen grains.

\subsection{Natural Pollination}

This is carried out by biotic and abiotic agents. Natural pollination is commonly practiced in some traditional oases and in places where the palms are very high and pose a risk for workers to climb. Natural pollination has a negative effect on crop yields, as well as the need for a large number of male palms, due to its inefficiency [5,49]. Plantations that use this pollination technique commonly experience high percentages of parthenocarpic fruit and low FSP. Therefore, this type of pollination does not guarantee high yields, so an artificial technique is necessary for commercial date production $[59,60]$.

\subsection{Hand Pollination with Fresh Male Spikelets Placement}

The Assyrians of ancient Mesopotamia practiced artificial pollination of date palms as early as 4500 B.C. $[12,61]$. Their method of pollination was to place strands of male inflorescences into the strands of female inflorescences. This method is traditional to many farmers. It consists of cutting the strands of a newly opened male inflorescence (Figure 5A) and placing two to six of these strands (depending on the size of the inflorescence), lengthwise and upside down, between the strands of the female inflorescence. A string is tied around the female inflorescence (Figure 5B) to hold the male strands in place $[3,62]$. This method requires more labor, worker skill, and DPP than the other methods.

\subsection{Hand Pollination with Dry Pollen}

Hand pollination with dry pollen is a more efficient use of DPP, since the pollen can be mixed in various proportions with wheat flour, talc, ground date bunch remains, and other inert filler agents $[4,49,63]$. Mixing proportions vary by cultivar, and can range from 1:1 to 1:8 DPP per diluting agent used. It also allows adequate control of DPP at the time of pollination. Hand pollination is generally done by sprinkling dried pollen grains on the female inflorescence.

\subsubsection{Hand Dusting of Pollen}

Various tools are used for hand dusting of pollen on the female inflorescence. The use of a squeeze bulb containing the mixture of pollen and flour (Figure 5C) is a very common method in Mexico and the USA [5]. In Peru, a plastic bottle with a lid with holes that allows the pollen to escape when pressed is used. Likewise, a small manual insecticide duster, known as a puffer, has also been used to pollinate with dry pollen [64]. Depending on the size of the inflorescence, it is sprayed two to three times on the inflorescence. 

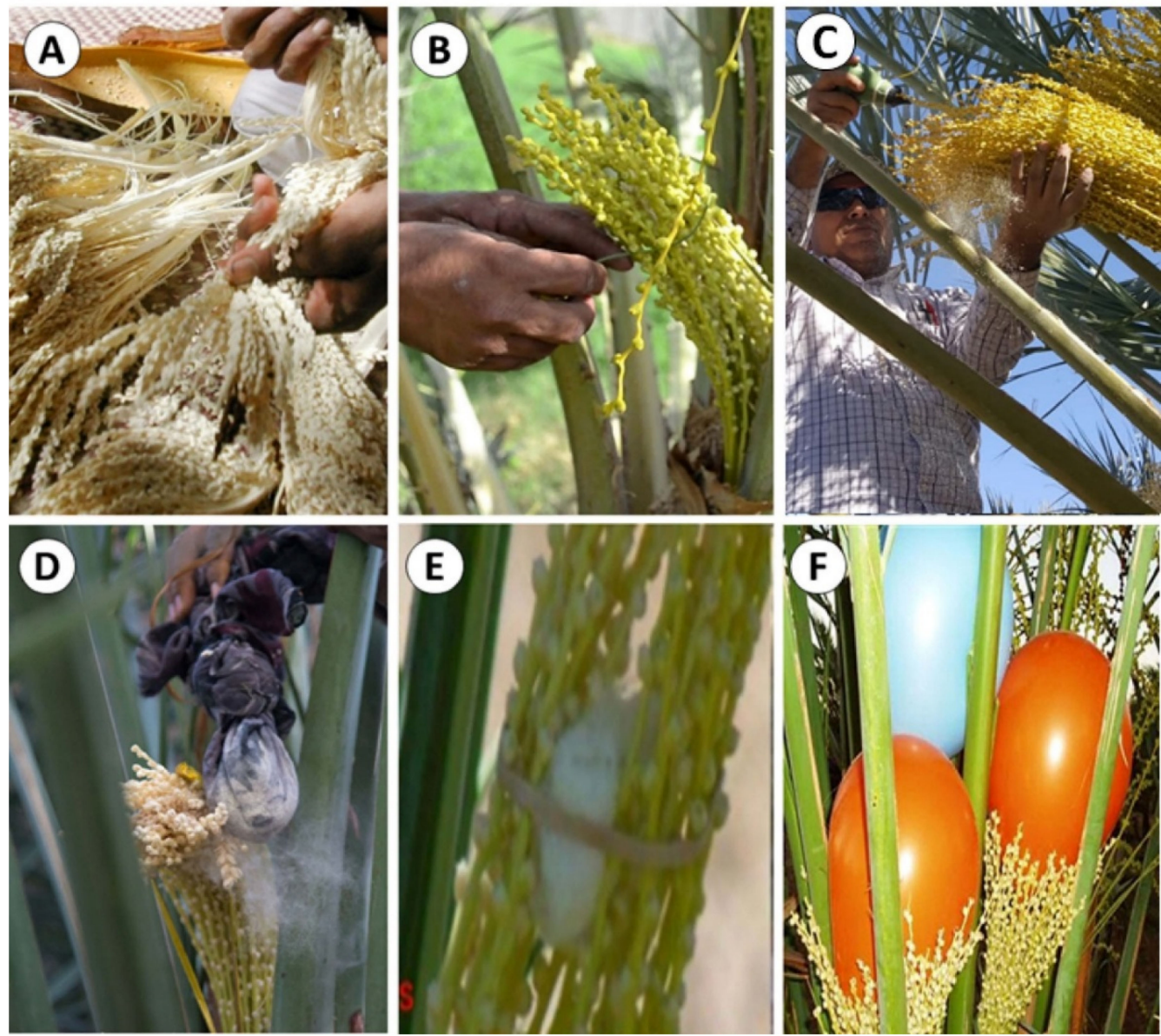

Figure 5. Pollination with male strands and dry pollen. (A) Separation of strands of a male inflorescence. (B) Embedding of male strands in the middle of a female inflorescence and securing with a string for its containment. (C) Pollination using a squeeze bulb. (D) Use of a cloth filled with DPP. (E) Cotton pieces embedded in the female inflorescence. (F) Common party balloons containing DPP inside. Source: Images A, B, D, E, and F (Adapted from $[16,63,64]$ ). Image C (Photo by Ricardo Salomón-Torres).

\subsubsection{Cloth Bag Containing Pollen}

Extracted, dried DPP is concentrated in the middle of a piece of cloth; the outer parts of the cloth are lifted and used to tie a knot, resulting in a ball of pollen contained in the cloth (like a stocking) [49]. This is struck against the inflorescence, allowing the pollen to filter through the cloth pores (Figure 5D). In order to reach tall or distant inflorescences, a long stick is attached to the knot of the fabric [65].

\subsubsection{Cotton Pieces and Common Balloons}

Walnut-sized pieces of cotton are dusted with dry pollen, and one to two pieces are embedded in the central part of the female inflorescence (Figure 5E) [3,49]. In Alice Springs, Australia, they are experimenting with common party balloons, containing a mixture of pollen and wheat flour. One balloon is placed on each female cluster waiting for them to burst and release the pollen into the inflorescence (Figure 5F) [66].

\subsubsection{Sponge Strips}

An alternative to the traditional pollination method is the use of sponge strips $(25 \mathrm{~cm}$ long, $1.5 \mathrm{~cm}$ thick, and $\mathrm{cm}$ wide) loaded with fresh DPP. One to three pieces are inserted in the middle of a female inflorescence, depending on its size [67]. This method is recom- 
mended when seeking efficient use of DPP in places where pollen is scarce and difficult to obtain.

\subsection{Pollination with Liquid Suspension Pollen}

This pollination method is being widely promoted due to the good results obtained. It can be done with a manual sprayer (Figure 6A) or using a mechanism with pressurized water suspension (Figure 6B). It is commonly a mixture of water with DPP at proportions from 0.5 to $4 \mathrm{~g}$ pollen per $\mathrm{L}$ water. Approximately $100 \mathrm{~mL}$ is sprayed on each inflorescence with a hand sprayer (Figure 6C) [62,68]. The liquid suspension is sometimes mixed with additional elements, such as $10 \%$ sucrose and 20 ppm GA3, which contribute to a better FSP [32].

\subsection{Mechanical Pollination with Dry Pollen}

Mechanization of date production has been adopted in recent years to increase production and improve agricultural efficiency, even reaching the use of artificial intelligence in pollination processes [69]. Automation processes have allowed solving some problems in the industry such as shortage of skilled workers, peak operating times, high costs, work intensity, etc. [2].
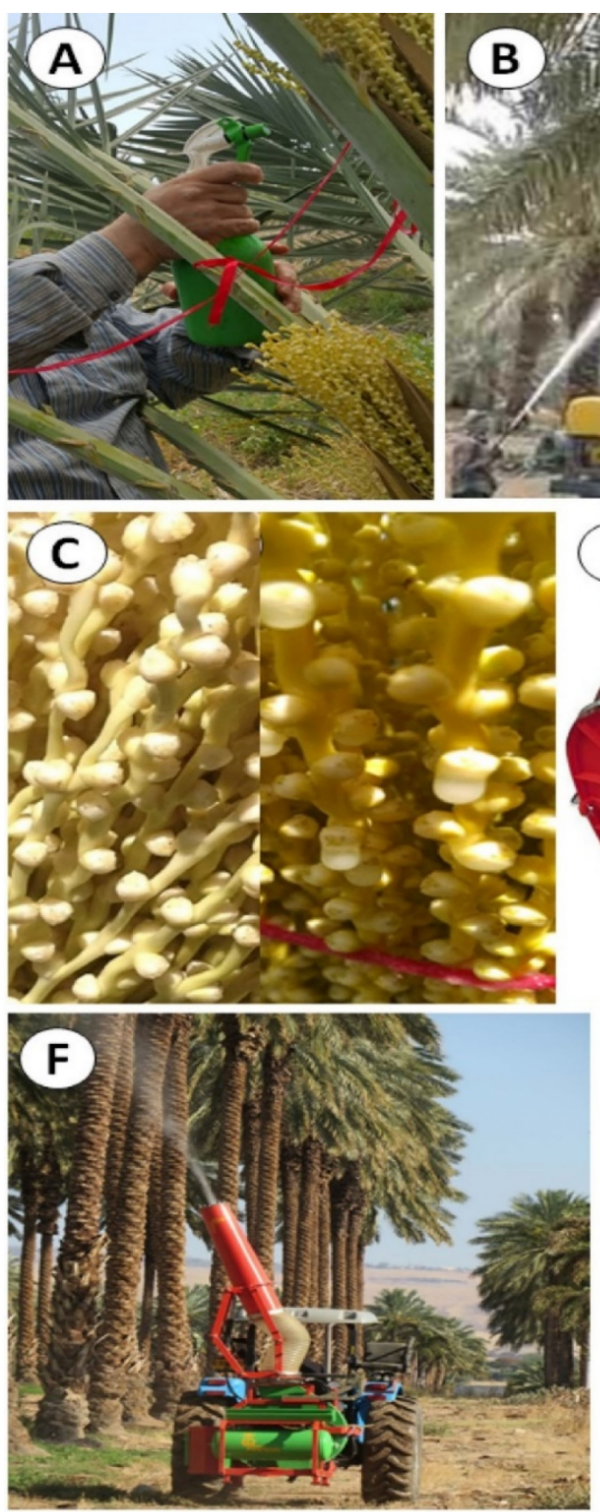

Figure 6. Cont.
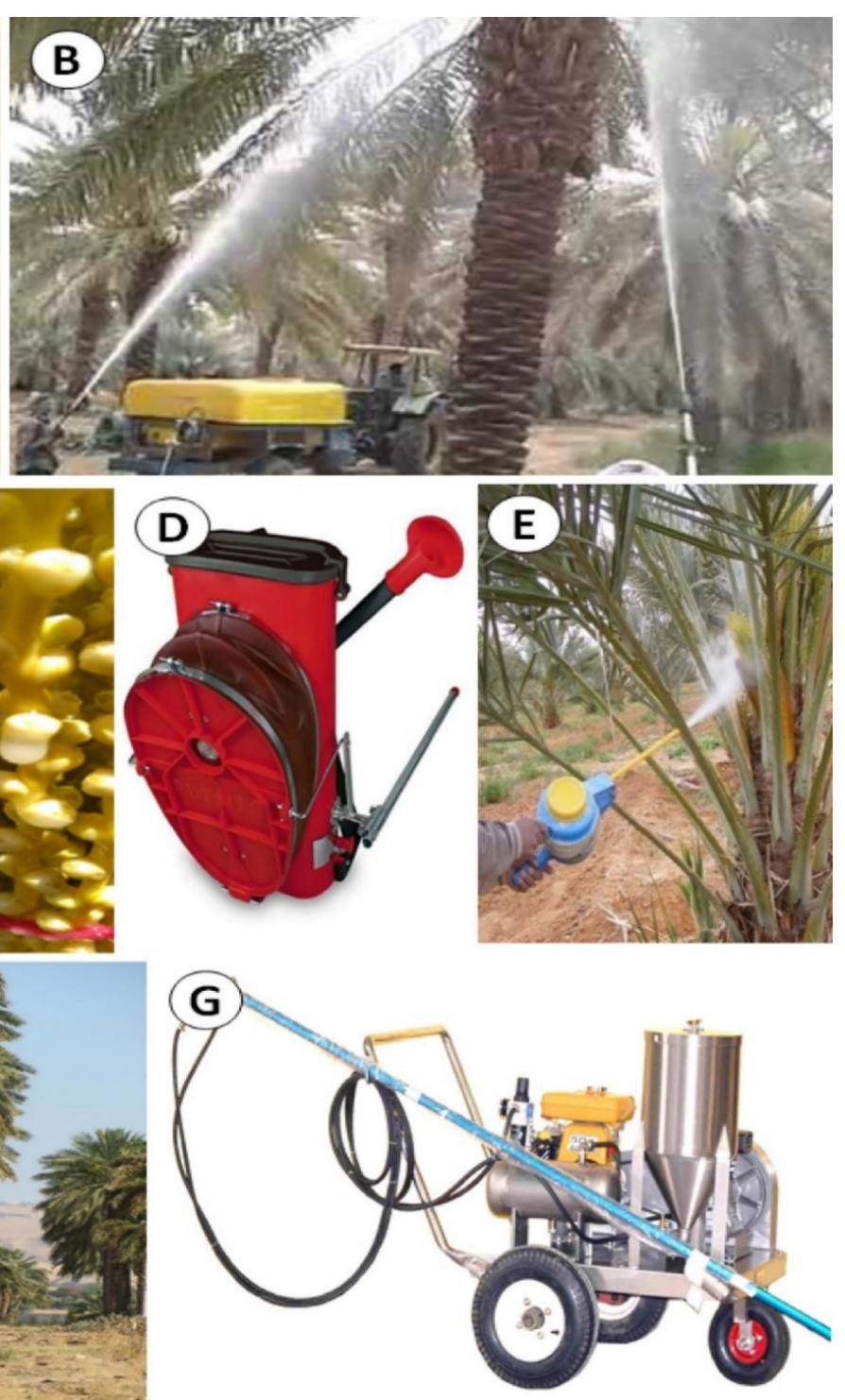

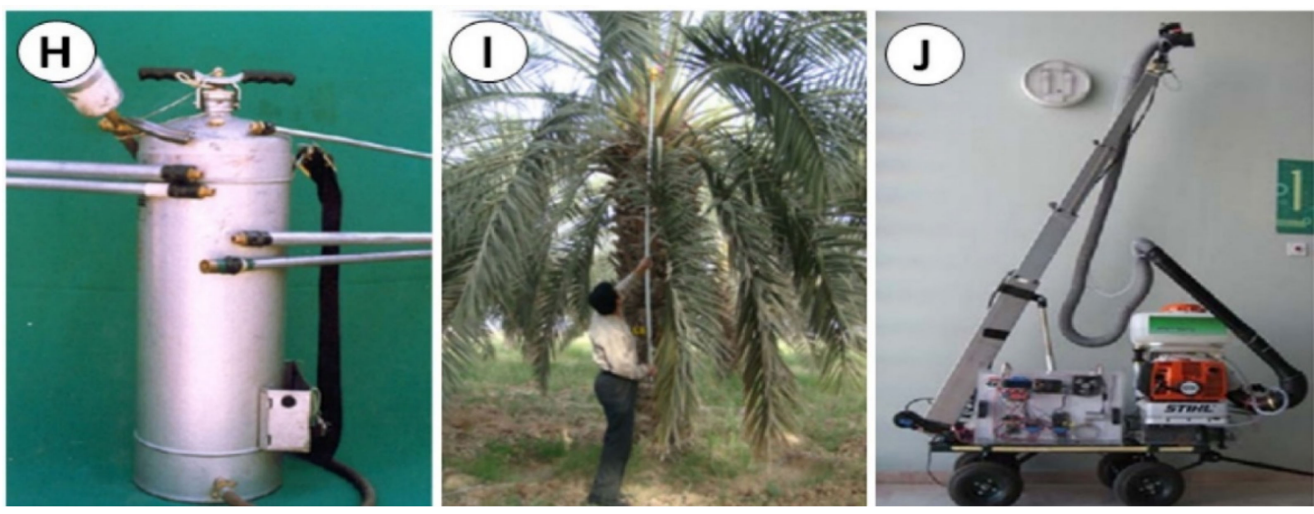

Figure 6. Date palm pollination methods using liquid and dry pollen. (A) Hand pollination with liquid suspension. (B) Pollination with a liquid suspension using a mechanism mounted on a tractor for high pressure delivery. (C) Inflorescence before and after liquid pollination. (D,E) Manual machines for pollination with dry DPP. (F) Pollination machine with a hydraulic mechanism. (G) Motorized duster. (H) Pressurized sprayer. (I) Palm pollination using an electric pollinator. (J) Prototype of a pollinating robotic arm using artificial intelligence. Source: Images A, B, D, E, G (Adapted from [16]). Image C (Photo by Ricardo Salomón-Torres). Image F (courtesy of Agrom Agricultural Machinery, LTD, www.agrommachine.com; accessed on 22 July 2020). Images H, I, J (Adapted from [49,60,69]).

\subsubsection{Pollen Mechanical Spraying}

Recently the use of manual mechanical sprinklers for pollination has been observed. These devices contain a simple mechanism, which through manual action generates air pressure into the device, expelling dry pollen through a small tube (Figure $6 \mathrm{D}, \mathrm{E}$ ).

\subsubsection{Pollen Spraying Machine}

A pollen spraying machine, attached to a tractor, consists of a hydraulic air cannon capable of vertical and horizontal adjustment. The cannon propels the pollen by means of an air current to the crown of the palm, up to $22 \mathrm{~m}$ in height. A single operator using this machine can pollinate more than 350 palms per hour [11]. The use of this technology has only been observed in highly industrialized countries such as Israel and the United States (Figure 6F). A disadvantage is that a greater amount of pollen is required.

\subsubsection{Motorized Pollen Duster}

This mechanical device consists of a stainless steel air tank, air pump, connection hoses, pollinator tubes, pollen hopper, rubber connection hoses, safety valve, and other components (Figure 6H) [49]. This apparatus is used as a pressurized sprayer from the ground. Its telescopic tube, up to $10 \mathrm{~m}$ long, can carry pollen to the crown of the palm, facilitating the pollination of selected female inflorescences without climbing the palm [70]. There is also a hand operated duster version, which includes a small piston pump connected to a reservoir and mounted on a set of aluminum pipes, while the motorized duster version includes a small compressor, operated by a gasoline engine (Figure 6G) [7]. This equipment is portable, can be operated by one man, and is similar to a backpack sprayer, and a worker can pollinate 150-200 palms daily [63].

\subsubsection{Date Palm Pollinator Electrical Device}

This is an electrical device with a DPP peripheral dispersal system [60]. It consists of an extendable aluminum pole, a dispenser with a pollen tank and an air distributor, and a thin tube connected to the dispenser and bent at a $45^{\circ}$ angle to facilitate pollination, with a nozzle at the end. The user operates a remote control with which the pollen dispersal mechanism is controlled. It is operated from the ground and does not require climbing the palm (Figure 6I). 


\subsubsection{Aircraft}

Pollination through the use of aircraft is still used in some parts of Israel [45]. In the Coachella Valley in California, USA, helicopters and fixed-wing aircrafts were experimented with in the 1960s and 1970s. However, low FSP were observed, up to five times the amount of pollen was consumed, and it was not economically viable [3].

\subsubsection{Robotic Prototype}

This device consists of a robotic arm and a computer controlled sprayer, which are guided by a computer sensing system that is capable of identifying inflorescences with a camera. This system seeks to manage pollen consumption with maximum precision in its use. Currently an experimental prototype to scale has been developed (Figure 6J) [69].

\section{Summary}

DPP is a good source of minerals, vitamins, and amino acids, with high nutritional value, which can be used as an excellent natural dietary food supplement for humans [71]. It can also be considered as a functional food, due to its high content of flavonoid compounds and bioactive volatile unsaturated fatty acids, which have an important role as antioxidants, anti-cancer factors, and promoters in human nutrition [72]. Based on these nutritional properties, a recently developed study evaluated the fortification of yogurt with DPP, concluding that it provided improved viscosity, syneresis, and water retention capacity; this could be considered as a symbiotic functional yogurt [73].

Another use of DPP has been in traditional or folk medicine, where it has been used to treat male infertility, while the consumption of male flowers has been used to improve fertility [74]. Currently, it is used as a dietary supplement to increase libido and improve fertility in both women and men $[75,76]$. A recent study reported that DPP intake in male patients induces a significant increase in testosterone levels and in the follicle stimulating hormone. It also improves the percentages of total and progressive sperm motility [77]. Ancient Egyptian culture used it as a rejuvenating medicinal agent [44]. Today there is a decreasing trend in human fertility rates, mainly in industrialized countries, and the use of DPP can be a tool in addressing that problem [78].

The Food and Agriculture Organization of the United Nations (FAO) generally recommends a ratio of 1:50 (male:female) palms for modern plantations with artificial pollination [3], which coincides with research from Egypt and Israel [6,45]. However, to define this proportion precisely, various aspects must be considered such as the cultivar, pollination method, number of inflorescences in each palm, amount of pollen in each application, and amount of pollen produced. Researchers from Libya, Morocco, and Syria report that for the cultivars, pollination methods, and cultivation practices used in those countries, successful pollination requires one male palm for every 25 female palms $[9,79,80]$.

Asynchronous maturation of female and male inflorescences refers to the male inflorescences maturing after the female inflorescences rather than before, as is normal. This phenomenon occurs frequently in date palms, and may be due to the effect of low or high temperature stress on the reproductive organs [50].

The vast majority of date farmers continue to extract pollen manually, which means that more workers dedicated to this activity are employed and that the process takes longer. The use of automated equipment requires a large initial investment, but is more efficient than manual extraction and can be carried out by a single person. In both manual and automated DPP extraction, the DPP is not damaged and remains viable. A great advantage of farmers who have male palms on their plantations is that they can store surplus DPP for the following season and thus prevent a possible delay in pollination. Conservation of DPP can be in sealed plastic containers in a common refrigerator maintaining a constant temperature, at a low cost for the farmer.

The term viability in DPP refers its status of being alive and able to complete postpollination events until fertilization is complete [56]. DPP can remain viable for a long time if kept dry [53]. Various studies evaluating the viability of dry DPP after storage at various 
temperatures (ambient $\left.\left(5-30{ }^{\circ} \mathrm{C}\right), 3-4{ }^{\circ} \mathrm{C},-20{ }^{\circ} \mathrm{C},-80{ }^{\circ} \mathrm{C},-196{ }^{\circ} \mathrm{C}\right)$ generally found that preservation of viability is increased at lower temperatures $[50,53,54,81]$; however, some varieties maintain a higher viability than others [53,81]. Preservation at $-20{ }^{\circ} \mathrm{C}$ is considered better for the growers, since the equipment is more accessible than that required for preservation at lower temperatures (cryopreservation). An empirical test used by Mexican date farmers is to mix a little pollen with water. If the pollen grains do not aggregate into a mass, the DPP is viable.

The selection of the preservation method, as well as the DPP viability test, will depend on the storage capacity, the number of palms, the diversity of cultivars, and the economic capacity of each farmer. Generally, it is a good practice to carry some pollen over into the following season.

A scientometric analysis with the search topic "pollination method" was performed using the Bibliometrix software [82] and ScientoPy [83], which extracted information from the Scopus dataset (www.scopus.com, accessed on 22 July 2020). This analysis revealed that the date-producing countries that have most evaluated pollination methods have been Egypt, Saudi Arabia, Pakistan, Oman, Iran, Iraq, and Jordan. Evaluating the efficiency of pollination methods, researchers from these countries have compared at least two methods of the following: (1) natural (wind), (2) strand placement (traditional method, 2-10 strands), (3) hand pollen dusting (any hand method, mixing dry pollen with flour or talc in various proportions), (4) dusting with hand or motorized pollinator (mechanical/electrical device), and (5) pollen in water suspension (hand spray).

Poor dispersion of DPP in the inflorescence and the effects of environmental factors such as high humidity, rain, low temperatures, and strong winds may have a negative effect on pollination efficiency [1]. When this happens, the fruit does not develop its pulp or its seed, all three carpels develop into small non-commercial fruits, or the fruit aborts. This phenomenon is known as parthenocarpy. Figure 7B,C shows examples of parthenocarpic fruit in the date palm.

The methods that achieve a pollination efficiency of $60-80 \%$ of the female inflorescences are considered as satisfactory, and with this a good FSP will be achieved [3] (Figure 7A).

Table 2 summarizes the efficiency of different pollination methods evaluated in various countries, where the efficiency of each method was evaluated through its FSP. Studies carried out in Egypt evaluated the traditional pollination method (strands placement) against water suspension and hand pollen dusting, concluding that DPP in water suspension and hand pollen dusting were the most effective methods [84-86]. In the first study, the traditional method had the highest FSP due to the excessive number of strands in the bunch, and an activation material (boric and ascorbic acids, treacle, and vinasse) resulted in a higher FSP [84]. Other studies have added a solution of sucrose, glycerin, and GA3 to the DPP suspension to increase FSP [3]. The second study worked with dry pollen and proportions of wheat flour, determining that a mixture including $20 \%$ pollen was the most efficient method [85]. This work also evaluated the stimulation and acceleration of pollen germination using a solution of $12 \%$ sucrose, $0.1 \mathrm{~g} \mathrm{~K}_{2} \mathrm{SO}_{4}, 0.2 \mathrm{~g} \mathrm{MgCl}_{2}, 0.3 \mathrm{~g} \mathrm{Ca}\left(\mathrm{NO}_{3}\right)_{2}$, $0.1 \mathrm{~g} \mathrm{H}_{3} \mathrm{BO}_{3}, 200 \mathrm{mg} / \mathrm{L}$ vitamin B1, $50 \mathrm{~mL} / \mathrm{L}$ Vitamin B6, and $1.0 \mathrm{mg} / \mathrm{L}$ Vitamin B12 prior to pollination; treatments receiving this treatment had the highest FSP. The third study added to its hand dusting treatments a natural growth activator called "Milagro", which is extracted from flower pollen; this addition improved the FSP [86]. 

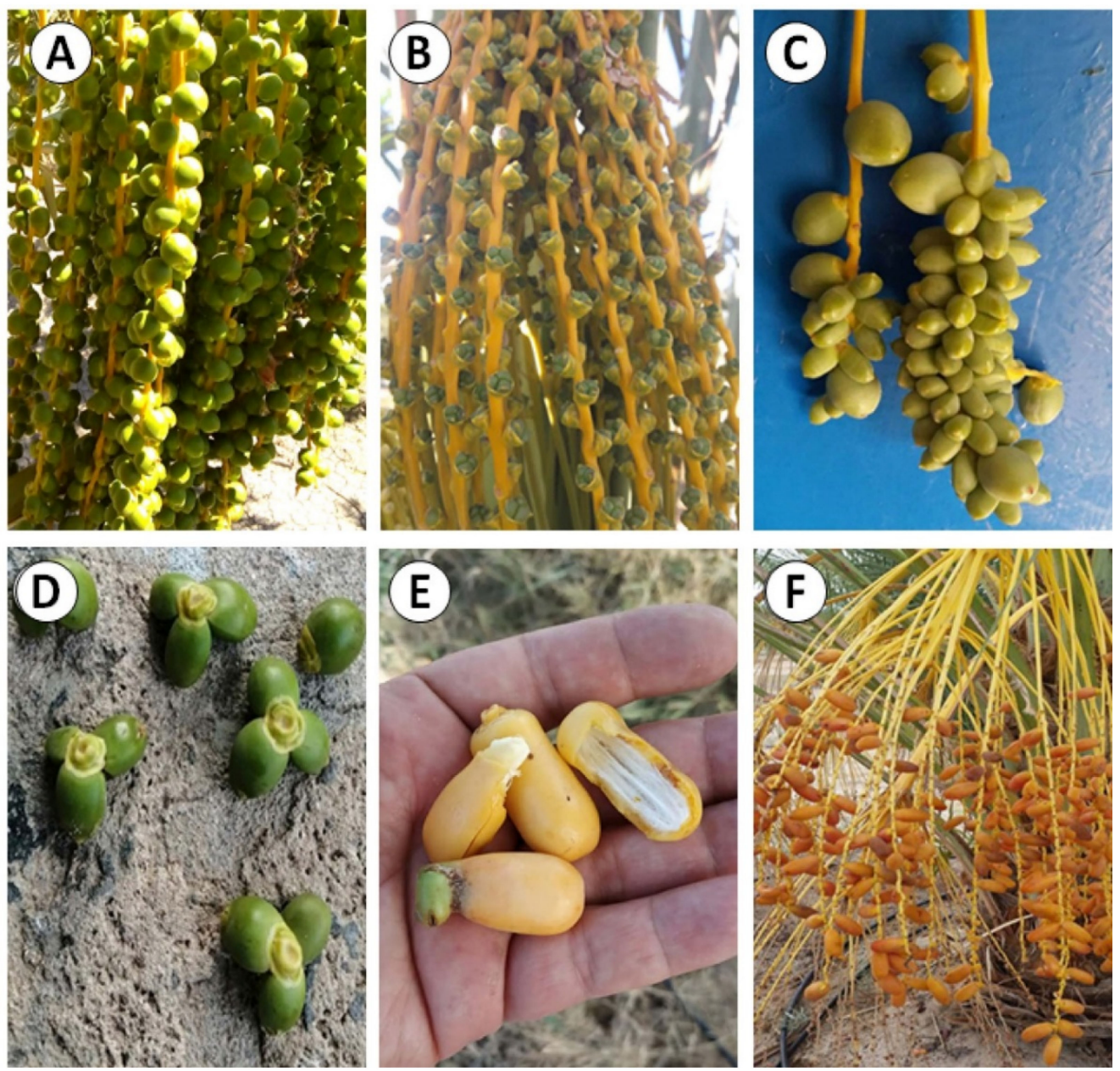

Figure 7. Parthenocarpic fruit in the date palm. (A) Date fruits resulting from good pollination. $(B, C)$ Parthenocarpic date fruits resulting from naturally pollinated inflorescences, low compatibility between the male and female palms, or pollination outside the receptive time of the female inflorescence. (D) Fruit aborted with triplet parthenocarpic fruits. (E,F) Ripe dates lacking seeds, due to parthenocarpy. Source: Images A, F (Photo by Ricardo Salomón-Torres). Images B-E (Adapted from [16]).

Table 2. Efficiency comparison of the different pollination methods on various date palm cultivars.

\begin{tabular}{|c|c|c|c|c|c|}
\hline Pollination Method & Treatments & Fruit Set $(\%)$ & Cultivars & Palms & Country \\
\hline $\begin{array}{l}\text { Hand spraying of } \\
\text { pollen suspension } \\
\text { Hand spraying of } \\
\text { pollen suspension } \\
\text { Strands placement }\end{array}$ & $\begin{array}{c}\text { Liquid pollen }(1.5 \mathrm{~g} / \mathrm{L})+0.2 \text { or } 2 \mathrm{~g} \text { boric or ascorbic } \\
\text { acids }+10 \% \text { Egyptian treacle or } 10 \% \text { vinasse } \\
\text { Liquid pollen }(3 \mathrm{~g} / \mathrm{L})+0.2 \text { or } 2 \mathrm{~g} \text { boric or ascorbic } \\
\text { acids }+10 \% \text { Egyptian treacle or } 10 \% \text { vinasse } \\
10 \text { strands } / \text { bunch }\end{array}$ & $\begin{array}{l}48.19 \\
54.44 \\
59.72\end{array}$ & Zaghloul & 8 & Egypt [84] \\
\hline $\begin{array}{l}\text { Strands placement } \\
\text { Hand pollen duster } \\
\text { Hand pollen duster } \\
\text { Hand pollen duster }\end{array}$ & $\begin{array}{c}5 \text { strands } / \text { bunch } \\
\text { Dry pollen }+ \text { wheat flour }(1: 20 \text { ratio) } \dagger \\
\text { Dry pollen }+ \text { wheat flour }(1: 10 \text { ratio }) \dagger \\
\text { Dry pollen }+ \text { wheat flour }(1: 5 \text { ratio })+\end{array}$ & $\begin{array}{c}26.71 \\
26.99 \\
28.95 \\
32.3\end{array}$ & Hayany & 32 & Egypt [85] \\
\hline $\begin{array}{l}\text { Dusting hand } \\
\text { Dusting hand } \\
\text { Dusting hand }\end{array}$ & $\begin{array}{c}2 \mathrm{~g} \text { pollen }+3 \mathrm{~g} \text { filler material } \\
1 \mathrm{~g} \text { Milagro }+4 \mathrm{~g} \text { filler material } \\
1 \mathrm{~g} \text { pollen }+1 \mathrm{~g} \text { Milagro }+3 \mathrm{~g} \text { filler material }\end{array}$ & $\begin{array}{l}54.7 \\
59.2 \\
65.1\end{array}$ & $\begin{array}{l}\text { Zaghloul, } \\
\text { Samany }\end{array}$ & 9 & Egypt [86] \\
\hline $\begin{array}{l}\text { Strands placement } \\
\text { Strips of sponge }\end{array}$ & $\begin{array}{c}2-3 \text { strands/bunch } \\
\text { Dry pollen }+ \text { wheat flour (1:4 ratio) }+\end{array}$ & $\begin{array}{c}69.1 \\
67.03\end{array}$ & Khalas & 20 & Saudi Arabia [67] \\
\hline $\begin{array}{l}\text { Strands placement } \\
\text { Portable pollen duster } \\
\text { Portable pollen duster } \\
\text { Portable pollen duster }\end{array}$ & $\begin{array}{c}5 \text { strands } / \text { bunch } \\
\text { Dry pollen }+ \text { wheat flour }(1: 5 \text { ratio })+ \\
\text { Dry pollen }+ \text { wheat flour }(1: 10 \text { ratio }) \dagger \\
\text { Dry pollen }+ \text { wheat flour }(1: 15 \text { ratio }) \dagger\end{array}$ & $\begin{array}{c}44.75 \\
37.5 \\
32.25 \\
33.55\end{array}$ & $\begin{array}{l}\text { Khalas, } \\
\text { Sheshi }\end{array}$ & 12 & Saudi Arabia [70] \\
\hline
\end{tabular}


Table 2. Cont.

\begin{tabular}{|c|c|c|c|c|c|}
\hline Pollination Method & Treatments & Fruit Set (\%) & Cultivars & Palms & Country \\
\hline \multirow{4}{*}{$\begin{array}{l}\text { Natural pollination } \\
\text { Strands placement } \\
\text { Dusting hand } \\
\text { Hand spraying of } \\
\text { pollen suspension }\end{array}$} & By wind & 26.03 & \multirow{4}{*}{ Khalas } & \multirow{4}{*}{12} & \multirow{4}{*}{ Saudi Arabia [87] } \\
\hline & 5 strands/bunch & 68.67 & & & \\
\hline & Dry pollen + wheat flour (1:9 ratio) + & 82.07 & & & \\
\hline & Liquid pollen $(3 \mathrm{~g} / \mathrm{L})$ & 85.71 & & & \\
\hline Natural pollination & By wind & 32.52 & \multirow{5}{*}{ Hillawi } & \multirow{5}{*}{2} & \multirow{5}{*}{ Pakistan [63] } \\
\hline Strands placement & 5 strands/bunch & 51.93 & & & \\
\hline Dusting hand & Dry pollen & 45.94 & & & \\
\hline Dusting with pollinator & Dry pollen & 60.76 & & & \\
\hline Dusting with pollinator & Dry pollen + talc & 40.93 & & & \\
\hline \multirow{4}{*}{$\begin{array}{l}\text { Hand spraying of } \\
\text { pollen suspension }\end{array}$} & Liquid pollen ( $1 \mathrm{~g} / \mathrm{L})$ & 74.67 & \multirow{4}{*}{$\begin{array}{l}\text { Khadrawy, } \\
\text { Zahidi }\end{array}$} & \multirow{4}{*}{24} & \multirow{4}{*}{ Pakistan [88] } \\
\hline & Liquid pollen $(2 \mathrm{~g} / \mathrm{L})$ & 79.67 & & & \\
\hline & Liquid pollen (3 g/L) & 84.5 & & & \\
\hline & Liquid pollen $(4 \mathrm{~g} / \mathrm{L})$ & 86 & & & \\
\hline Natural pollination & By wind & 12.65 & \multirow{4}{*}{ Zahidi } & \multirow{4}{*}{40} & \multirow{4}{*}{ Iraq [89] } \\
\hline Strands placement & $2-3$ strands/bunch & 62.43 & & & \\
\hline Dusting mechanical & Dry pollen $(8 \%)$ & 53.59 & & & \\
\hline Dusting mechanical & Dry pollen (16\%) & 57.41 & & & \\
\hline Dusting hand & Dry pollen & 100 & \multirow{5}{*}{$\begin{array}{l}\text { Medjool, } \\
\text { Barhee }\end{array}$} & \multirow{5}{*}{4} & \multirow{5}{*}{ Jordan [68] } \\
\hline \multirow{4}{*}{$\begin{array}{l}\text { Hand spraying of } \\
\text { pollen suspension }\end{array}$} & Liquid pollen $(1 \mathrm{~g} / \mathrm{L})$ & 72.5 & & & \\
\hline & Liquid pollen $(2 \mathrm{~g} / \mathrm{L})$ & 81 & & & \\
\hline & Liquid pollen $(3 \mathrm{~g} / \mathrm{L})$ & 81 & & & \\
\hline & Liquid pollen (4 g/L) & 91.5 & & & \\
\hline Dusting hand with brush & Dry pollen + wheat flour (1:1 ratio) & 31.74 & Medjool & 5 & Mexico [4] \\
\hline
\end{tabular}

In investigations in Saudi Arabia, the hand spraying of a pollen suspension proved to be the most effective; however, due to ease of operation and cost reduction, the use of a motorized pollinator was recommended $[67,70,87]$. The first study evaluated the use of the traditional method (Section 5.3) against strips of sponge impregnated with dry pollen and flour. No significant differences were found [67]. The second work analyzed the traditional method against the use of a portable pollen duster with dry DPP and flour, obtaining better results from the traditional method; this could be due to the low proportions of pollen used in the duster [70]. The third study determined that the liquid pollination method ( $3 \mathrm{~g}$ pollen/L water) obtained the highest FSP, followed by hand dusting of dry pollen and flour in a 1:9 ratio. In addition, the percentage of parthenocarpic fruit was evaluated for each pollination method. Natural pollination $(7.81 \%)$ resulted in the highest proportion of parthenogenic fruit, followed by strands placement $(3.66 \%)$, hand dusting $(0.64 \%)$, and pollen suspension $(0.32 \%)$ [87].

In Pakistan it was reported that hand spraying of a pollen suspension at $4 \mathrm{~g}$ pollen/L water was the best treatment for liquid pollination [88], while for pollination with dry pollen, it was dusting with a mechanic pollinator [63].

In Iraq, a study was made with dry pollen at a DPP proportion of $16 \%$ [89]. The traditional method (Section 5.3) resulted in the highest FSP (62.42\%), while mechanical dusting resulted in a FSP of $57.41 \%$ of FSP.

In Jordan, liquid pollination and hand dusting methods were evaluated [68]. The hand dusting hand method resulted in 100\% FSP, while the liquid pollen suspension with $4 \mathrm{~g}$ pollen/L water was $91.50 \%$ [68]. In general, in this study the high FSPs were reported in all treatments. However, for the "Medjool" cultivar, high FSPs require more cultural inputs, since it is necessary to thin the bunch in order to obtain larger fruits.

In Mexico, a study was carried out where the effect of DPP sources on the fruit quality of the "Medjool" cultivar was evaluated using hand dusting [4]. On average, a FSP of $31.74 \%$ was obtained, which is a low efficiency. However, this could have been due to the use of a brush, which is not generally used for pollination of date palms.

Finally (data not shown in Table 2), in Oman, hand pollen dusting and dusting with a motorized pollinator methods were found to be the most efficient; however, the results did 
not present any clear evidence of the superiority of one method over the others $[7,90,91]$. In Iran, the performance of an electric hand pollination device was evaluated against hand pollination by dusting and motorized pollinator. The difference between the three methods was not significant; however due to handling, cost, and operation, the use of the electrical device was recommended [60].

Natural wind pollination occurs commonly in regions where large populations of uncultivated seedling date palms grow, resulting in about $50 \%$ of the population being male. This practice favors the development of parthenocarpic fruits without any commercial value [88]. The traditional pollination technique can have a high fertilization efficiency if the number of strands inserted into each bunch is increased. However, this has several disadvantages, such as a higher consumption of pollen, increased costs, and a single person can only fertilize of 200-250 palm trees in the period of receptivity of the inflorescences. This technique also requires several ascents of each palm, which may damage the palm crown and increases the risk of falling [47].

Most researchers in different countries have concluded that the natural method and strand placement are the pollination techniques that result in the lowest yields. Therefore, mechanical pollination is recommended, since unlike the hand pollen duster, it is used at ground level, does not require climbing the palm, has a lower cost and shorter time of operation, and eliminates the risk of accidents. The use of an atomizing machine allows pollination of more than 250 palms in eight hours by a single person [92]. Although it has the drawback of initial cost and maintenance cost, mechanical pollination is one of the most attractive alternatives, since it can reduce labor by $50-70 \%$ [89].

Table 2 shows in a general way that the treatments with water suspension present high FSP, with very low DPP consumption. Liquid suspensions in combination with germination stimulants such as boric acid or ascorbic acid also require only low proportions of DPP per liter of water (1-4 g pollen/L water) [84]. This method of pollination is being strongly promoted by an International Center for Agricultural Research in the Dry Areas (ICARDA) project in the Persian Gulf countries, because it is faster, less expensive, and more effective [93].

An innovative method for the pollination of date palms is being developed in Oman involving the use of pollinating drones. With the use of drones and artificial intelligence (AI) in the One Million Date Palm Trees Project, the aim is to reduce dependence on large amounts of labor and enter the so-called "fourth industrial revolution in the agricultural sector" [94].

Finally, another aspect not mentioned in any study is the pollen trade. In various open air markets in Arab countries, it is common to see people selling fresh male spathes. In Mexico and the USA, it is possible to buy a gallon of DPP (approximately $2 \mathrm{~kg}$ ) at a cost of 300-450 USD.

\section{Conclusions}

The method of pollen extraction will depend on the economic capacity of the producer, but a mechanical-automated method offers multiple advantages over a manual one. The most efficient pollination methods evaluated were (1) dusting with a motorized pollinator, since it presents acceptable FSPs and other great advantages over other methods; and (2) liquid spraying of a pollen suspension, since it presents the highest FSPs, with low consumption of DPP.

However, date palm producers should evaluate which method is the most effective for them under their production conditions. A low FSP can reduce the amount of hand thinning of the fruit in the bunch, which is necessary to obtain commercial fruit quality in some cultivars. Likewise, the viability of the source of the DPP used and the agroclimatic conditions for each country should be considered. In addition, regarding the consumption needs of DPP for pollination, it will be necessary to count one to two male palms for every 50 females, according to the pollination method used. 
As the use of artificial intelligence advances, the development of technology for the use of a pollinator drone could be a viable solution to reduce costs, since it could identify ready-to-pollinate inflorescences, the amount of pollen to use, and would be operated by a single person. This same apparatus could be used in the pesticide application and thus have a double utility.

Likewise, use of DPP as a functional food, and for attending the decreasing human fertility rates in industrialized countries, may open an opportunity for its use and valorization.

Author Contributions: Conceptualization: R.S.-T. and R.K.; software: J.P.G.-V. and J.A.S.-U.; investigation: R.S.-T., J.P.G.-V. and L.S.-S.; writing-original draft preparation: R.S.-T. and R.K.; writing-review and editing: N.O.-U., R.V.-A. and C.V.-A.; visualization: R.S.-T., J.P.G.-V. and L.S.-S. All authors have read and agreed to the published version of the manuscript.

Funding: This research received no external funding.

Institutional Review Board Statement: Not applicable.

Informed Consent Statement: Not applicable.

Data Availability Statement: Not applicable.

Conflicts of Interest: The authors declare no conflict of interest. The funders had no role in the design of the study; in the collection, analyses, or interpretation of data; in the writing of the manuscript, or in the decision to publish the results.

\section{References}

1. Al-Khalifah, N.S.; Askari, E. Growth Abnormalities Associated with Micropropagation of Date Palm. In Date Palm Biotechnology; Springer International Publishing: Berlin/Heidelberg, Germany, 2011; pp. 205-219.

2. Mostaan, A. Mechanization in Date Palm Pollination. In Dates: Production, Processing, Food, and Medicinal Values, 1st ed.; Manickavasagan, A., Essa, M.M., Sukumar, E., Eds.; CRC Press: London, UK, 2012; pp. 129-140.

3. Zaid, A.; Arias-Jimenez, E.J. Date Palm Cultivation; Food and Agricultural Organization: Rome, Italy, 2002; ISBN 92-5-104863-0.

4. Salomon-Torres, R.; Ortiz-Uribe, N.; Villa-Angulo, R.; Villa-Angulo, C.; Norzagaray-Plasencia, S.; García-Verdugo, C.D. Effect of pollenizers on production and fruit characteristics of date palm (Phoenix dactylifera L.) cultivar Medjool in Mexico. Turk. J. Agric. For. 2017, 41, 338-347. [CrossRef]

5. Ortiz-Uribe, N.; Salomón-Torres, R.; Krueger, R. Date Palm Status and Perspective in Mexico. Agriculture 2019, 9, 46. [CrossRef]

6. Shawky, B.A.; El-Sharabasy, S.F. Date Palm Status and Perspective in Egypt. In Date Palm Genetic Resources and Utilization: Africa and the Americas, 1st ed.; Al-Khayri, J.M., Mohan, S., Johnson, D.V., Eds.; Springer: New York, NY, USA, 2015; Volume 1, pp. 75-124.

7. El-Mardi, M.; Labiad, S.; Consolacion, E.; Addelbasit, K. Effect of pollination methods and pollen dilution on some chemical constituents of Fard Dates at different stages of fruit development. Emir. J. Food Agric. 1995, 7, 1. [CrossRef]

8. Soliman, S.S.; Alebidi, A.I.; Al-Saif, A.M.; Al-Obeed, R.S.; Al-Bahelly, A.N. Impact of pollination by pollen-grain-water sus-pension spray on yield and fruit quality of segae date palm cultivar (Phoenix dactylifera L.). Pak. J. Bot. 2017, 49, 119-123.

9. Sudhersan, C.; Sudhersan, J.; Ashkanani, J.; Al-Sabah, L. Date Palm Status and Perspective in Kuwait. In Date Palm Genetic Resources and Utilization: Asia and Europe, 1st ed.; Al-khayri, J.M., Mohan-Jain, S., Johnson, D.V., Eds.; Springer: New York, NY, USA, 2015; Volume 2, pp. 299-322.

10. Khairi, M.M.A. Date Palm Status and Perspective in Sudan. In Date Palm Genetic Resources and Utilization: Africa and the Americas, 1st ed.; Al-Khayri, J.M., Mohan, S., Johnson, D.V., Eds.; Springer: New York, NY, USA, 2015; Volume 1, pp. 169-192.

11. AGROM. Development, Design and Manufacture of Agricultural and Industrial Machines. Available online: https://www. agrommachine.com/home-new-en (accessed on 22 July 2020).

12. Halbritter, H.; Ulrich, S.; Grímsson, F.; Weber, M.; Zetter, R.; Hesse, M.; Buchner, R.; Svojtka, M.; Frosch-Radivo, A. Illustrated Pollen Terminology; Springer International Publishing: Berlin/Heidelberg, Germany, 2018.

13. Crang, R.; Lyons-Sobaski, S.; Wise, R. Plant Anatomy A Concept-Based Approch to the Structure of Seed Plants, 1st ed.; Springer: New York, NY, USA, 2019; ISBN 978-3-319-77208-0.

14. Daoud, A.; Malika, D.; Bakari, S.; Hfaiedh, N.; Mnafgui, K.; Kadri, A.; Gharsallah, N. Assessment of polyphenol composition, antioxidant and antimicrobial properties of various extracts of Date Palm Pollen (DPP) from two Tunisian cultivars. Arab. J. Chem. 2019, 12, 3075-3086. [CrossRef]

15. Reuvani, O. Phoenix Dactylifera. In Handbook of Flowering, 1st ed.; Halevy, A.H., Ed.; CRC Press: Boca Raton, FL, USA, 1985; pp. 343-349.

16. Facebook. School of Palm and Date Lovers. 2020. Available online: https://www.facebook.com/groups/1431837897104498 (accessed on 2 July 2020). (In Arab). 
17. Tisserat, B.; DeMason, D. A scanning electron microscope study of pollen of Phoenix (Arecaceae). J. Am. Soc. Hortic. Sci. 1982, $107,883-887$.

18. Zaid, A.; De Wet, P.F. Climatic requirements of date palm. In Date Palm Cultivation. Plant Production and Protection Paper 156; Zaid, A., Arias-Jimenez, E.J., Eds.; FAO: Rome, Italy, 2002; pp. 57-72.

19. Reuvani, O. Date. In Handbook of Fruit Set and Development, 1st ed.; Monseliese, S.P., Ed.; CRC Press: Boca Raton, FL, USA, 1986; pp. 119-144.

20. Al-Khalifah, N.S. Metaxenia: Influence of pollen on the maternal tissue of fruits of two cultivars of date palm (Phoenix dactylifera L.). Bangladesh J. Bot. 2006, 35, 151-161.

21. Swingle, W.T. Metaxenia in the date palm: Possibly a hormone action by the embryo or endosperm. J. Hered. 1928, 19, 257-268. [CrossRef]

22. Soliman, S.S.; Al-Obeed, R.S. Investigations on the pollen morphology of some date palm males (Phoenix dactylifera L.) in Saudi Arabia. Aust. J. Crop Sci. 2013, 7, 1355-1360.

23. Hajian, S.; Hamidi-Esfahani, Z. Date Palm Status and Perspective in Iran. In Date Palm Genetic Resources and Utilization: Asia and Europe, 1st ed.; Al-khayri, J.M., Mohan-Jain, S., Johnson, D.V., Eds.; Springer: New York, NY, USA, 2015; Volume 2, pp. 19-48.

24. Aleid, S.M.; Al-Khayri, J.M.; Al-Bahrany, A. Date Palm Status and Perspective in Arabia Saudi. In Date Palm Genetic Resources and Utilization: Asia and Europe, 1st ed.; Al-Khayri, J.M., Mohan-Jain, S., Johnson, D.V., Eds.; Springer: New York, NY, USA, 2015; Volume 2, pp. 49-96.

25. Salomón-Torres, R.; Ortiz-Uribe, N.; Sol-Uribe, J.A.; Villa-Angulo, C.; Villa-Angulo, R.; Valdez-Salas, B.; García-González, C.; Monroy, C.G.I.; Norzagaray-Plasencia, S. Influence of different sources of pollen on the chemical composition of date (Phoenix dactylifera L.) cultivar Medjool in México. Aust. J. Crop. Sci. 2018, 12, 1008-1015. [CrossRef]

26. Salomón-Torres, R.; Sol-Uribe, J.A.; Valdez-Salas, B.; García-González, C.; Krueger, R.; Hernández-Balbuena, D.; Norzagaray-Plasencia, S.; García-Vázquez, J.P.; Ortiz-Uribe, N. Effect of Four Pollinating Sources on Nutritional Properties of Medjool Date (Phoenix dactylifera L.) Seeds. Agriculture 2020, 10, 45. [CrossRef]

27. Nixon, R.W. Metaxenia in Dates. Proc. Am. Soc. Hort. Sci. 1956, 32, 221-226.

28. Nixon, R.W. The direct effect of pollen on the fruit on the date palm. J. Agric. Res. 1928, 36, 97-128.

29. Denney, J.O. Xenia Includes Metaxenia. HortScience 1992, 27, 722-728. [CrossRef]

30. Maryam, J.; Muhammad, J.; Naqvi, S.A. Storage and Viability Assessment of Date Palm Pollen. In Date Palm Biotechnology Protocols; Al-Khayri, J.M., Jain, S.M., Johnson, D.V., Eds.; Springer: New York, NY, USA, 2017; Volume II, pp. 3-13.

31. Bacha, M.A.A.; Aly, M.A.; Al-Obeed, R.S.; Abdul-Rahman, A.O. Compatibility relations in some date palm cultivars (Phoenix dactylifera L.). Agric. Sci. 2000, 12, 81-95.

32. Iqbal, M.; Niamatullah, M.; Munir, M. Effect of various Dactylifera males pollinizer on pomological traits and economical yield index of cv's Shakri, Zahidi and Dhakki date palm (Phoenix dactylifera L.). J. Anim. Plant Sci. 2012, 22, 376-383.

33. Mustafa, E.; Heiba, S.; Saleh, M.; Ashour, N.; Mohamed, D.A.; El-Mig, M.A. Effect of Different Pollinizer Sources on Yield, Fruit Characteristics and Phylogenetic Relationships with Amhat Cv. Date Palm (Phoenix dactylifera L.) in Egypt Using RAPD Markers. Int. J. Agric. Res. 2014, 9, 331-343. [CrossRef]

34. Shahid, M.A.; Iqbal, M.; Niamatullah, M. Response of Male Pollinizers in Fruit Set, Yield and Quality of Date Palm (Phoenix dactylifera L.). Cv. Dhakki. Sarhad J. Agric. 2017, 33, 108-116. [CrossRef]

35. Outghouliast, H.; Messaoudi, Z.; Touhami, A.O.; Douira, A.; Haddou, L.A. Effect of pollen source on yield and fruits quality of date palm (Phoenix dactylifera L.) CV. "Mejhoul” in moroccan oases. Plant Cell Biotechnol. Mol. Biol. 2020, 21, 60-69.

36. Sebii, H.; Karra, S.; Bchir, B.; Ghribi, A.M.; Danthine, S.M.; Blecker, C.; Attia, H.; Besbes, S. Physico-Chemical, Surface and Thermal Properties of Date Palm Pollen as a Novel Nutritive Ingredient. Adv. Food Technol. Nutr. Sci. Open J. 2019, 5, 84-91. [CrossRef]

37. Zeid, H.M.A.; Shiha, M.A.; Shehata, A.A. Comparative Study of Pollen Grains Morphology and Phytochemical Constituents of Some Saudi Arabian Date Palm (Phoenix dactylifera L.) Cultivars. Int. J. Curr. Microbiol. Appl. Sci. 2019, 8, 2800-2809. [CrossRef]

38. Al-Samarai, A.H.; Al-Salihi, F.G. Phytochemical constituents and nutrient evaluation of date palm (Phoenix dactylifera L.) pollen grains. Tikrit J. Pure Sci. 2016, 21, 56-62.

39. Al-Anber, L.J.M. Estimation of the Content of Lipids and Fatty Acids in Pollen of Phoenix dactylifera (Date Palm) from Basrah, Iraq. Rev. Bol. Quim. 2017, 34, 9-13.

40. Hassan, H.M.M. Chemical Composition and Nutritional Value of Palm Pollen Grains. Glob. J. Biotechnol. Biochem. $2011,6,1-7$.

41. Yang, Z.-H.; Kitami, Y.; Takata, Y.; Okura, T.; Hiwada, K. Targeted Overexpression of CCAAT/Enhancer-Binding Protein- $\delta$ Evokes Enhanced Gene Transcription of Platelet-Derived Growth Factor $\alpha$-Receptor in Vascular Smooth Muscle Cells. Circ. Res. 2001, 89, 503-508. [CrossRef]

42. Al-Farsi, M.A.; Lee, C.Y. Nutritional and Functional Properties of Dates: A Review. Crit. Rev. Food Sci. Nutr. 2008, 48, 877-887. [CrossRef]

43. Salomón-Torres, R.; Ortiz-Uribe, N.; Valdez-Salas, B.; Rosas-González, N.; García-González, C.; Chávez, D.; Córdova-Guerrero, I.; Díaz-Rubio, L.; Haro-Vázquez, M.D.P.; Mijangos-Montiel, J.L.; et al. Nutritional assessment, phytochemical composition and antioxidant analysis of the pulp and seed of medjool date grown in Mexico. PeerJ 2019, 7, e6821. [CrossRef] [PubMed]

44. Tahvilzadeh, M.; Hajimahmoodi, M.; Rahimi, R. The Role of Date Palm (Phoenix dactylifera L.) Pollen in Fertility. J. Evidence-Based Integr. Med. 2016, 21, 320-324. [CrossRef] [PubMed] 
45. Cohen, Y.; Glasner, B. (Buki) Date Palm Status and Perspective in Israel. In Date Palm Genetic Resources and Utilization: Asia and Europe, 1st ed.; Al-Khayri, J.M., Mohan, S., Johnson, D.V., Eds.; Springer: New York, NY, USA, 2015; Volume 2, pp. $265-298$.

46. Shaheen, M. Evaluation of date palm males using pollen viability and ultrastructure. Acta Hortic. 2004, 632, 37-43. [CrossRef]

47. Wertheimer, M. La Pollination du palmier dattier (Phoenix dactylifera L.). Fruits 1957, 12, 305-313.

48. YouTube. Collecting Medjool Pollen. 2009. Available online: https://www.youtube.com/watch?v=dcfeomBk_CA (accessed on 25 July 2020).

49. Hajian, S. Fundamentals of Pollination in Date Palm Plantations in Iran. In Proceedings of the International Conference on Mango and Date Palm: Culture and Export, Faisaabad, Pakistan, 20-23 June 2005; University of Agriculture: Faisaabad, Pakistan, 2005; pp. 252-259.

50. Mesnoua, M.; Roumani, M.; Salem, A. The effect of pollen storage temperatures on pollen viability, fruit set and fruit quality of six date palm cultivars. Sci. Hortic. 2018, 236, 279-283. [CrossRef]

51. Ream, C.L.; Furr, J.R. The period of receptivity of pistillate flowers and other factors affecting set of date fruit. Date Grow. Inst. Rep. $1969,46,28-29$.

52. Reuvani, O. Pistil receptivity of "Khadrawi", "Zahidi" and "Deglet Noor" date flowers. Date Grow. Inst. Rep. 1970, 47, 3-4.

53. Maryam, M.; Fatima, B.; Salman Haider, M.; Abbas Naqvi, S.; Nafees, M.; Ahmad, R.; Ahmad Khan, I. Evaluation of pollen viability in date palm cultivars under different storage temperatures. Pak. J. Bot. 2015, 47, 377-381.

54. Anushma, P.L.; Vincent, L.; Rajesekharan, P.E.; Ganeshan, S. Pollen storage studies in date palm (Phoenix dactylifera L.). Int. J. Chem. Stud. 2018, 6, 2640-2642.

55. Nixon, R.W.; Carpenter, J.B. Growing Dates in the United States. U.S. Dept. of Agriculture, Agriculture Information Bulletin Number 207; USDA: Washington, DC, USA, 1978; p. 63.

56. Shivanna, K.R.; Rangaswamy, N.S. Pollen Biology. A Laboratory Manual; Springer: Berlin, Germany, 1992; ISBN 978-3-540-55170-6.

57. Ismail, O.M.; Zohair, M.M. Date Palm Pollen Germination and Growth Susceptibility to Different pH Medium. J. Agric. Food Technol. 2013, 3, 26-30.

58. Heslop-Harrison, J.S. Cytological Techniques to Assess Pollen Quality. In Sexual Plant Reproduction, 1st ed.; Cresti, M., Tiezzi, A., Eds.; Springer: Berlin, Germany, 1992; pp. 41-48.

59. Siddiq, M.; Greiby, I. Overview of Date Fruit Production, Postharvest handling, Processing, and Nutrition. In Dates: Postharvest Science, Processing Technology and Health Benefits, 1st ed.; Siddid, M., Aleid, S.M., Kader, A.A., Eds.; Willey Blackweel: Oxford, UK, 2014; pp. 1-28.

60. Mostaan, A.; Marashi, S.; Ahmadizadeh, S. Development of a new date palm pollinator. Acta Hortic. 2010, 882, 315-320. [CrossRef]

61. Jaradat, A.A. Biodiversity, Genetic Diversity, and Genetic Resources of Date Palm. In Date Palm Genetic Resources and Utilization: Africa and the Americas, 1st ed.; Al-Khayri, J.M., Mohan-Jain, S., Johnson, D.V., Eds.; Springer: New York, NY, USA, 2015; Volume 1, pp. 19-74.

62. Awad, M. Pollination of date palm (Phoenix dactylifera L. 'Lulu') with pollen grains water suspension. Acta Hortic. 2010, 882, 337-343. [CrossRef]

63. Ullah, M.; Ahmad, F.; Iqbal, J.; Imtiaz, M.; Raza, M.K. Effects of Different Pollination Methods on Fruit Quality and Yield of Date Palm Candidate Line Hillawi. J. Environ. Agric. Sci. 2018, 17, 55-62.

64. Nixon, R.W. Growing Dates in the United States. Agriculture Information Bulletin Number 207; USDA: Washington, DC, USA, $1966 ;$ p. 56.

65. Foods and Tools. Energy Date Bites and Pollination of the Date Palm. 2016. Available online: https://foodandtools.com/2016/0 3/28/energy-date-bites-and-pollination-of-the-date-palm/ (accessed on 22 July 2020).

66. Brain, C. Party Ballons Used to Pollinate Date Palms. ABC News, 11 December 2012. Available online: https://www.abc.net.au/ news / rural/2012-12-11/party-balloons-used-to-pollinate-date-palms / 6128256(accessed on 22 July 2020).

67. Ben Abdallah, A.; Al-Wusaibai, N.A.; Al-Fehaid, Y. Assessing the Efficiency of Sponge and Traditional Methods of Pollination in Date Palm. J. Agric. Sci. Technol. B 2014, 4, 267-271. [CrossRef]

68. Abu-Zahra, T.R.; Shatnawi, M.A. New Pollination Technique in Date Palm (Phoenix dactylifera L.) Cv. "Barhee" and "Medjool" under Jordan Valley Conditions. Am-Euras. J. Agric. Environ. Sci. 2019, 19, 37-42. [CrossRef]

69. Shapiro, A.; Korkidi, E.; Rotenberg, A.; Furst, G.; Namdar, H.; Sapir, B.; Mishkin, M.; Ben-Shahar, O.; Edan, Y. A Robotic Prototype for Spraying and Pollinating Date Palm Trees. In Proceedings of the ASME 2008 9th Biennial Conference on Engineering Systems Design and Analysis, Haifa, Israel, 7-9 July 2008; ASME International: Haifa, Israel, 2008; pp. 431-436.

70. Al-Wusaibai, N.A.; Ben Abdallah, A.; Al-Husainai, M.S.; Al-Salman, H.; Elballaj, M. A comparative study between mechanical and manual pollination in two premier Saudi Arabian date palm cultivars. Indian J. Sci. Technol. 2012, 5, 2487-2490. [CrossRef]

71. Bishr, M.; Desoukey, S.Y. Comparative study of the nutritional value of four types of Egyptian palm pollen. J. Pharm. Nutr. Sci. 2012, 2, 50-56.

72. Vladimir-Knezevic, S.; Blazekovic, M.B.; Stefan, M.; Babac, M. Plant Polyphenols as Antioxidants Influencing the Human Health In Phytochemicals as Nutraceuticals_Global Approaches to Their Role in Nutrition and Health, 1st ed.; Rao, V., Ed.; InTech: Rijeka, Croatia, 2012; pp. 155-180.

73. El-Kholy, W.M.; Soliman, T.N.; Darwish, A.M.G. Evaluation of date palm pollen (Phoenix dactylifera L.) encapsulation, impact on the nutritional and functional properties of fortified yoghurt. PLoS ONE 2019, 14, e0222789. [CrossRef] [PubMed]

74. Rasekh, A.; Jashni, H.K.; Rahmanian, K.; Jahromi, A.S. Effect of Palm Pollen on Sperm Parameters of Infertile Man. Pak. J. Biol. Sci. 2015, 18, 196-199. [CrossRef] [PubMed] 
75. Afanasyev, B.V. Health Benefits and Nutritional Aspects of Date Palm Pollen. Canad. J. Clin. Nutr. 2020, 8, 1-3. [CrossRef]

76. Abdi, F.; Roozbeh, N.; Mortazavian, A.M. Effects of date palm pollen on fertility: Research proposal for a systematic review. BMC Res. Notes 2017, 10,1-4. [CrossRef]

77. Saeed, H.S.M.; Osman, B.; El-Hadiyah, T.M.H.; Mohamed, M.S.; Osman, W.J.A.; Abdoon, I.H.; Mothana, R.A. Date Palm Pollen Grains as a Potential Manager for Male Sub-fertility: A Clinical Trial. J. Pharm. Res. Int. 2020, 32, 83-95. [CrossRef]

78. Skakkebaek, N.E.; Jørgensen, N.; Main, K.M.; Meyts, E.R.-D.; Leffers, H.; Andersson, A.-M.; Juul, A.; Carlsen, E.; Mortensen, G.K.; Jensen, T.K.; et al. Is human fecundity declining? Int. J. Androl. 2006, 29, 2-11. [CrossRef] [PubMed]

79. Sedra, M.H. Date Palm status and Perspective in Morocco. In Date Palm Genetic Resources and Utilization: Africa and the Americas, 1st ed.; Al-Khayri, J.M., Mohan-Jain, S., Johnson, D.V., Eds.; Springer: New York, NY, USA, 2015; Volume 1, pp. $257-324$.

80. Haider, N. Date Palm Status and Perspective in Syria. In Date Palm Genetic Resources and Utilization: Asia and Europe, 1st ed.; Al-Khayri, J.M., Mohan-Jain, S., Johnson, D.V., Eds.; Springer: New York, NY, USA, 2015; pp. 387-422.

81. El Kadri, N.; Ben Mimoun, M. In Vitro Germination of Different Date Palm (Phoenix Dactylifera L.) Pollen Sources from Southern Tunisia under the Effect of Three Storage Temperatures. Int. J. Fruit Sci. 2020, 20, S1519-S1529. [CrossRef]

82. Aria, M.; Cuccurullo, C. Bibliometrix: An R-tool for comprehensive science mapping analysis. J. Inf. 2017, 11, 959-975. [CrossRef]

83. Ruiz-Rosero, J.; Ramirez-Gonzalez, G.; Viveros-Delgado, J. Software survey: ScientoPy, a scientometric tool for topics trend analysis in scientific publications. Science 2019, 121, 1165-1188. [CrossRef]

84. Abdalla, M.G.M.; El-salhy, A.; Mostafa, R.A.A. Effect of some Pollination Treatments on Fruiting of Zaghloul Date Palm Cul-tivar Under Assiut Climatic Condition. Assiut. J. Agric. Sci. 2011, 42, 350-362.

85. El-Dengawy, E.-R. Improvement of the Pollination Technique in Date Palm. J. Plant Prod. 2017, 8, 307-314. [CrossRef]

86. Hafez, O.M.; Saleh, M.A.; Mostafa, E.; El-Shamma, M.; Maksoud, M. Improving Pollination Efficiency, Yield and Fruit Quality of Two Date Palm Cultivars using Growth Activator. Int. J. Agric. Res. 2013, 9, 29-37. [CrossRef]

87. Munir, M. A comparative study of pollination methods effect on the changes in fruit yield and quality of date palm cultivar Khalas. Asian J. Agric. Biol. 2020, 8, 147-157. [CrossRef]

88. Munir, M. Influence of liquid pollination technique on fruit yield and physico-chemical characteristics of date palm cultivars Khadrawy and Zahidi. J. Biodivers. Environ. Sci. 2019, 15, 41-49.

89. Hamood, H.H.; Mawlood, E.A. The Effect of mechanical pollination on fruit set, yield and fruit characteristics of date palm (Phoenix dactylifera L.) Zahidi cultivar. Date Palm J. 1986, 4, 175-184.

90. El Mardi, M.; Said, F.A.J.A.; Sakit, C.B.; Al Kharusi, L.; Al Rahbi, I.; Al Mahrazi, K. Effect of pollination method, fertilizer and mulch treatments on the physical and chemical characteristics of date palm (Phoenix dactylifera) fruit I: Physical characteristics. Acta Hortic. 2007, 736, 317-328. [CrossRef]

91. Eimardi, M.; Esechie, H.; Al-Kharousi, L.; Abdelbasit, K. Effect of Pollination Method on Changes in Physical and Chemical Characteristics of Date Fruit During Development. J. Agric. Mar. Sci. 2002, 7, 21. [CrossRef]

92. Jamro, M.M.-U.-R. Production and quality of Date fruit in response to pollination methods. Pure Appl. Biol. 2020, 9, 1737-1742. [CrossRef]

93. ICARDIA. Steering Committee of Icarda's Led Date Palm Project in Gulf Countries Meets in Doha. 2017. Available online: https: / www.icarda.org/media/news/steering-committee-icardas-led-date-palm-project-gulf-countries-meets-doha (accessed on 30 July 2020).

94. Observer-Daily. Technology to Be Used for Pollinating Date Palms. 2018. Available online: https: / / www.omanobserver.om/ technology-to-be-used-for-pollinating-date-palms / (accessed on 30 July 2020). 